\title{
Loss of MAP Function Leads to Hippocampal Synapse Loss and Deficits in the Morris Water Maze with Aging
}

\author{
Qiu-Lan Ma, ${ }^{1,2}$ Xiaohong Zuo, ${ }^{1,2,4}$ Fusheng Yang, ${ }^{1,2}$ Oliver J. Ubeda, ${ }^{1,2}$ Dana J. Gant, ${ }^{1,2}$ Mher Alaverdyan, ${ }^{1,2}$ \\ Nicolae C. Kiosea, ${ }^{1,2}$ Sean Nazari, ${ }^{1,2}$ Ping Ping Chen, ${ }^{1,2}$ Fatiha Nothias, ${ }^{3}$ Piu Chan, ${ }^{4}$ Edmond Teng,,${ }^{1,2}$ \\ Sally A. Frautschy, ${ }^{1,2 *}$ and Greg M. Cole ${ }^{1,2 *}$ \\ ${ }^{1}$ Department of Neurology, University of California, Los Angeles, California 90095, ${ }^{2}$ Geriatric Research, Education and Clinical Center, Greater Los Angeles \\ Veterans Affairs Healthcare System, Los Angeles, California 90073, ${ }^{3}$ Axonal Regeneration and Growth/Physiopathologie des Maladies du Système Nerveux \\ Central, INSERM U952, Centre National de la Recherche Scientifique, Unité Mixte de Recherche 7224, Université Pierre et Marie Curie, 75005 Paris, France, \\ and ${ }^{4}$ Department of Neurobiology and Neurology, Beijing Institute of Geriatrics, Xuanwu Hospital, Capital Medical University, Beijing 10053, China
}

Hyperphosphorylation and accumulation of tau aggregates are prominent features in tauopathies, including Alzheimer's disease, but the impact of loss of tau function on synaptic and cognitive deficits remains poorly understood. We report that old (19-20 months; 0KO) but not middle-aged (8-9 months; MKO) tau knock-out mice develop Morris Water Maze (MWM) deficits and loss of hippocampal acetylated $\alpha$-tubulin and excitatory synaptic proteins. Mild motor deficits and reduction in tyrosine hydroxylase (TH) in the substantia nigra were present by middle age, but did not affect MWM performance, whereas $\mathrm{OKO}$ mice showed MWM deficits paralleling hippocampal deficits. Deletion of tau, a microtubule-associated protein (MAP), resulted in increased levels of MAP1A, MAP1B, and MAP2 in MK0, followed by loss of MAP2 and MAP1B in OKO. Hippocampal synaptic deficits in $\mathrm{OKO}$ mice were partially corrected with dietary supplementation with docosahexaenoic acid (DHA) and both MWM and synaptic deficits were fully corrected by combining DHA with $\alpha$-lipoic acid (ALA), which also prevented TH loss. DHA or DHA/ALA restored phosphorylated and total GSK3 $\beta$ and attenuated hyperactivation of the tau C-Jun N-terminal kinases (JNKs) while increasing MAP1B, dephosphorylated (active) MAP2, and acetylated $\alpha$-tubulin, suggesting improved microtubule stability and maintenance of active compensatory MAPs. Our results implicate the loss of MAP function in ageassociated hippocampal deficits and identify a safe dietary intervention, rescuing both MAP function and TH in OKO mice. Therefore, in addition to microtubule-stabilizing therapeutic drugs, preserving or restoring compensatory MAP function may be a useful new prevention strategy.

Key words: Alzheimer's disease; knock-out; MAPs; Morris Water Maze; synaptic markers; tau

\section{Introduction}

Microtubule associated proteins (MAPs) play well established and often overlapping roles in promoting microtubule assembly and stability in axons or dendrites, but also can bind filamentous actin, recruit signaling and heat shock proteins, and regulate

Received Aug. 8, 2013; revised Feb. 9, 2014; accepted March 11, 2014.

Author contributions: Q.-L.M., S.A.F., and G.M.C. designed research; Q.-L.M., X.Z., F.Y., O.J.U., D.J.G., M.A., N.C.K., S.N., P.P.C., S.A.F., and G.M.C. performed research; F.N. and P.C. contributed unpublished reagents/analytic tools; Q.-L.M., D.J.G., N.C.K., E.T. and S.A.F. analyzed data; Q.-L.M., S.A.F., and G.M.C. wrote the paper.

This work was supported by the National Institutes of Health (Grant AT003008 to G.M.C.; Grant P01AG16570 from the Alzheimer's Disease Research Center to G.M.C.; Grant RC1AG035878 to G.M.C. and S.A.F.; Grant AG13471 to G.M.C.; Grant U01 28583 to S.A.F.; and Grant R01AG021975 to S.A.F.), the Alzheimer's Association (Grant NIRG-0759659 to Q.L.M.), the UCLA Alzheimer's Disease Research Center Mary S. Easton Drug Discovery Program (G.M.C.), the UCLA Mary S. Easton Translational Center (G.M.C., S.A.F.), and David and Dr. Sharon Comden (S.A.F., G.M.C.). X.Z. was supported by the Beijing High Standard Health Human Resource Cultural Program (Grant e1e12 to P.P.C.). The polyclonal antibody to dephosphorylated, active MAP2 "MAP2 972" was provided by Jesus Avíla, PhD (Professor, Universidad Autónoma de Madrid, Spain).

The authors declare no competing financial interests.

*S.A.F. and G.M.C. contributed equally to this work.

Correspondence should be addressed to either Greg. M. Cole or Sally A. Frautschy, Mary S. Easton Translational Center, Veterans Greater Los Angeles Healthcare, 11301 Wilshire Blvd., Bldg. 113, Rm. 312, Los Angeles, CA 90073. E-mail: gmcole@ucla.edu or frautsch@ucla.edu.

DOI:10.1523/JNEUROSCI.3439-13.2014

Copyright $\odot 2014$ the authors $\quad 0270-6474 / 14 / 347124-13 \$ 15.00 / 0$ kinesin- and dynein-dependent transport along microtubules. Although MAPs can have unique distributions and function, most have multiple alternatively spliced isoforms, a conserved C-terminal domain with microtubule-binding repeats, and an $\mathrm{N}$-terminal projection domain (for review, see Dehmelt and Halpain, 2005).

The MAP tau is enriched in axons, but is also present in dendrites, where it modulates postsynaptic targeting of the Src kinase Fyn, an NMDA receptor substrate (Ittner et al., 2010). Although abundant clinical and animal data strongly support that tau aggregates exert a gain of toxic function (GOF) in neurodegenerative disease (Arriagada et al., 1992; Jicha et al., 1997; Gamblin et al., 2003; Guillozet et al., 2003; Santacruz et al., 2005), aberrant tau phosphorylation, aggregation involving microtubule-binding domains, or truncation of tau can result in loss of function (LOF) of tau that could also contribute to synaptic and cognitive dysfunction.

Separating LOF from GOF in Alzheimer's disease (AD) pathogenesis remains difficult. Supporting that LOF causes functional deficits, microtubule-stabilizing drugs are protective in $\mathrm{AD}$ models (Zhang et al., 2005). Weakening the LOF theory, adult tau knock-out (KO) mice exhibit no (Morris et al., 2013) or subtle 
deficits compared with AD or tauopathy models (Harada et al., 1994; Ikegami et al., 2000; Dawson et al., 2001; Denk and WadeMartins, 2009; Ke et al., 2012). The functional redundancy of MAPs may explain a limited impact of tau depletion in mouse models, making it difficult to translate the implications of LOF tau in human disease, particularly with aging.

One goal of the present study was to look at synaptic effects of tau deletion in relation to compensatory changes in other MAPs to determine whether aging could reveal deficits not apparent in young mice. We also examined treatment effects showing promise in the clinical setting and AD models to determine effects on preservation of other endogenously regulated MAP activities. One trial with the n-3 fatty acid docosahexaenoic acid (DHA) showed cognitive improvement in subjects lacking ApoE4 and with mild to moderate AD (Quinn et al., 2010); four other clinical trials suggested that DHA protects against cognitive decline in early stages of $\mathrm{AD}$ (Cole et al., 2010) and that increased dietary fish or DHA intake is associated with reduced AD risk. DHA limits $\mathrm{A} \beta$, $\mathrm{p}$-tau, and oxidative stress while improving neuronal survival signaling (for review, see Cole et al., 2010), but its impact on other MAPs is unknown. Therefore, aged tau KO mice were fed diets enriched in DHA, which is reported to modulate tau phosphorylation and ameliorate cognitive decline in early-stage AD patients and AD models (Calon et al., 2004; Chiu et al., 2008; Ma et al., 2009; Quinn et al., 2010). Because $\alpha$-lipoate (ALA), a lipophilic, mitochondrial protective antioxidant effectively improved cognition in Tg2576 mice (Quinn et al., 2007) and in a clinical trial (Shinto et al., 2014), we also fed the aged Tau KO mice DHA combined with ALA.

\section{Materials and Methods}

Animals. All animal procedures were approved by the local Institutional Animal Care Use Committee and performed with strict adherence to the current guidelines set out in the National Institutes of Health's Guide for the Care and Use of Laboratory Animals at the Association for Assessment and Accreditation of Laboratory Animal Care (AALAC)-accredited Greater Los Angeles VA Healthcare System. This study included the following cohorts of animals. Cohort A mice underwent Morris Water Maze (MWM) testing (except the DHA alone group), Western blotting (WB), and immunostaining data analysis, whereas Cohort B was used only for additional motor tests. Cohort A consisted of middle-aged animals: 8- to 9-month-old tau KO mice (MKO, $n=7)$ and age-matched C57BL/6J wild-type (WT) control mice $(n=8)$. Other groups included aged tau $\mathrm{KO}$ mice $(\mathrm{OKO})$ administered treatments starting at 14-15 months of age up to $19-20$ months. OKO groups included untreated controls $(n=9)$, DHA alone $(n=8)$, and DHA/ALA $(n=8)$. There was also a group of age-matched C57BL/6J WT control mice $(n=10)$. Cohort B mice consisted of animals used for additional motor tests: 2 - to 21-month-old WT ( $n=8), 2$ - to 3-month-old tau KO mice $(n=8$, data not shown), 8 -month-old tau KO mice $(n=5)$, 9-month-old tau KO mice $(n=6), 11$ - to 12 -month-old tau KO mice $(n=8)$, and 17- to 21 -month-old tau KO mice $(n=9)$. Both males and females were included and sex balanced. All mice were purchased from (The Jackson Laboratory) and were fed a commonly used breeder chow base diet (Mouse Diet 5015; LabDiet) containing $11 \%$ fat with $0.18 \% \omega$-3 fatty acid, which is higher fat content than standard chows to increase fertility. Unlike many standard chows, it does not contain fish meal. The tau KO mice on a C57BL/6J background (strain 004779) were originally generated by Dawson et al. $(2001,2010)$. Cohort A mice were tau KO mice from The Jackson Laboratory. For Cohort B, we mated female tau KO homozygote with male tau KO homozygote and age-matched C57BL/6J WT control mice with female C57BL/6J. Because there were no differences between MKO and middle-aged WT, Tau KO effects did not appear to be due to inbreeding. Further, we have subsequently produced additional generations of tau $\mathrm{KO}$ that exhibit similar deficits. In Cohort A, 14- to 15-month-old mice were fed PMI 5015 chow for 5 months.
There were three treatments: base diet PMI 5015 control; 0.6\% DHA (from DHASCO oil; Martek) or $0.6 \%$ DHA with $500 \mathrm{ppm} \alpha$-lipoate (ALA; Sigma Chemicals) added to base diet. Cohort B was used to examine developmental changes in motor function with aging in $\mathrm{KO}$ and $\mathrm{WT}$ mice from 2 to 21 months of age. At the end of drug and behavioral testing, mice were anesthetized with a lethal dose of pentobarbital (100 $\mathrm{mg} / \mathrm{kg}$ body weight) and perfused with a nonfixative buffer containing protease and phosphatase inhibitors as described previously (Lim et al., 2005). One hemibrain was immersion fixed in $4 \%$ paraformaldehyde and then frozen for cryosectioning, and the remaining hemibrain was dissected and snap-frozen in liquid nitrogen for biochemical analysis.

MWM. Spatial memory was assessed using the MWM test, as described previously (Morris, 1984). A circular tank (diameter $152 \mathrm{~cm}$, height $60 \mathrm{~cm}$, painted white) was filled with water $\left(23 \pm 1^{\circ} \mathrm{C}\right)$ to a depth of $40 \mathrm{~cm}$; the water was rendered opaque by the addition of nontoxic white paint. Distal spatial visual clues were provided in the form of different shaped objects on each wall of the room. A circular, white escape platform (diameter $15 \mathrm{~cm}$ ) was placed in the target quadrant (1), submerged $\sim 1 \mathrm{~cm}$ below the surface of the water, and placed halfway between the center of the pool and the tank wall. A video camera was mounted on the ceiling in the center of the pool, attached to the HVS Water 20/20 (HVS Image) tracking system to monitor swim paths and latencies, and the data were collected using HVS Water 20/20 Software (HVS Image). Acquisition trials ( 4 trials per block per day for $5 \mathrm{~d}$ ) were initiated by placing the mouse in the pool facing the wall of the tank from different randomly chosen start positions and the time required to find the invisible platform was recorded. A trial lasted until the mouse found the platform or until $60 \mathrm{~s}$ had elapsed. If the mouse did not find the platform within $60 \mathrm{~s}$, it was guided to the platform and placed on it for $15 \mathrm{~s}$. After the completion of each block of four trials, the mouse was dried and returned to its home cage. On day $6,24 \mathrm{~h}$ after the final acquisition trial, the platform was removed from the pool, and a probe trial lasting $60 \mathrm{~s}$ was performed; the time spent and path length in the target quadrant and the number of times the animals crossed the platform location were recorded. In the probe trial, the mouse was started facing the wall of the tank from the position opposite to the removed platform. Twenty-four hours after the probe trial, mice were trained to find a visible platform ( 4 trials/d for $1 \mathrm{~d}$ ) to confirm the absence of visual or motor deficits (data not shown).

Motor tests. Four tests of motor function were performed to measure coordination, muscle function, and motor deficits, as described previously (Guyenet et al., 2010). Each test was repeated three times and mice were given scores from 0 to 3 depending on the severity of deficits, with 0 signifying no deficits and 3 severe deficits. In the ledge test, mice were placed briefly on the cage's ledge. If the mouse walked along the ledge and descended into the cage gracefully, it was given a score of 0 ; if it fell off the ledge or refused to move, it was given a score of 3 . In the hindlimb clasping test, which is used to identify ataxia-like motor deficits, the mouse was lifted at the base of the tail and the hindlimb position observed for $10 \mathrm{~s}$. If the hindlimbs were consistently splayed outward, the mouse received a score of 0 ; if the hindlimbs were retracted or touching the abdomen for $>50 \%$ of the time suspended, it received a score of 3 . In the gait test, if the mouse walked normally using both hindlimbs and without the abdomen touching the ground, it received a 0 , but if it had difficulty walking forward and dragged its abdomen along the ground, it received a 3. Finally, the kyphosis test involved observation of the mouse walking to assess dorsal curvature of the spine caused by a loss of muscle tone. If the mouse easily straightened its spine as it walked, it received a score of 0 ; if the mouse displayed pronounced kyphosis sitting or walking, it received a score of 3 . The scores of motor tests were totaled to provide a generalized motor score number with a maximum of 12 for severe deficit to minimum of 0 , signifying no deficit.

WB analysis. Mouse brain hippocampal tissue samples were processed into two fractions. The first samples were sonicated in Tris-buffered saline (TBS) and then spun in the ultracentrifuge for $20 \mathrm{~min}$ at $100,000 \times$ $g$ to obtain supernatants (TBS, soluble-cytosol fraction). Pellets were then sonicated in immunoprecipitation lysis buffer containing $1 \%$ Triton X-100, $0.5 \%$ sodium deoxycholate, and $0.5 \%$ SDS and recentrifuged to obtain the lysis extract supernatants (membrano-cytoskeletal extract). 
TBS and lysis buffers contained protease and phosphatase inhibitors to prevent proteolysis and dephosphorylation, as described previously (Calon et al., 2004). For WB analysis, protein concentrations were determined using the Bio-Rad DC protein assay. Then, $30 \mu \mathrm{g}$ of protein for each sample were boiled in Laemmli loading buffer for 3 min, loaded onto each well of a 34 lane 7-20\% Tris-glycine gradient gel, electrophoresed, and then transferred to Immobilon-P PVDF membranes (Millipore; Ma et al., 2006). However, for detection of MAP1 and MAP2, 610 $\mu \mathrm{g}$ of protein were loaded. Blots were developed in the linear range with chemiluminescent detection and relative optical density on film scanned with a Bio-Rad densitometer (Calon et al., 2004).

Chemicals, reagents, and antibodies. All chemicals were purchased from Sigma-Aldrich unless otherwise stated. Antibody sources were mouse monoclonal antibody (mAb) to phospho-C-Jun N-terminal kinase (P-JNK; Thr183/Tyr185) and polyclonal antibody (pAb) to total JNK (Cell Signaling Technology); rabbit pAb to phospho-glycogen synthase kinase $3 \beta$ (P-GSK3 $\beta$; pY279/pY216); other mAbs used were to total anti-GSK3 $\alpha / \beta$ (Biosource), $\alpha$-tubulin (Millipore). mAbs to NR2B, PSD95, GABA-A, and MAP1B were from Millipore. We also used mAbs to drebrin (clone M2F6; MBL), NR1 (Advanced ImmunoChemical), MAP2, and synaptophysin (clone MAB368), as well as neurofilament antibody clone SMI-31 (Sigma), Polyclonal MAP1A was from Santa Cruz Biotechnology and phosphorylated MAP1B (P-MAP1B) was from Novus Biologicals. A polyclonal antibody named "MAP2 972" was the generous gift from Dr. J. Avíla (Universidad Autónoma de Madrid, Spain). This MAP2 972 antibody was raised against a nonphosphorylated peptide with the sequence RTPGTPG-TPSY (1616-1626 of MAP2), and this domain has been reported as an in vivo inactivating phosphorylation epitope in the proline-rich domain of the MAP2, where phosphorylation at Thr1620 and 1623 causes loss of MT binding and loss of 972 reactivity (Sánchez et al., 1995).

Confocal and light microscopy. For cryosectioning, hemibrains were mounted on the chuck with OCT (Tissue-Tek) mounting medium and then rotated so that sectioning revealed dorsal and ventral portions of coronal sections in accordance with the bregma micrographs in the Mouse Brain Atlas. For confocal and light microscopy, immunocytochemical staining (ICC), frozen formalin-fixed mouse brains were sectioned at a thickness of $12 \mu \mathrm{m}$, mounted on precleaned and precoated Superfrost Plus slides (Fisher Scientific), dried overnight, and slides stored in sealed boxes in a $-20^{\circ} \mathrm{C}$ freezer for two more days to let them dry cold before use. After slides with sections were removed from the freezer and allowed to equilibrate to room temperature, they were immersed in distilled water for $5 \mathrm{~min}$ followed by antigen unmasking solution (catalog \#H-3300; Vector Laboratories) and steaming for $15 \mathrm{~min}$. After washing in PBS with $0.3 \%$ Triton X-100 in TBS for 10 min, sections were incubated for $30 \mathrm{~min}$ at $37^{\circ} \mathrm{C}$ in a solution containing $5 \%$ normal goat serum and $3 \%$ bovine serum albumin (BSA) in TBS. These sections are then sequentially labeled with three primary antibodies and their respective fluorophore-labeled secondary antibody. Sections were incubated with the first primary antibody overnight at $4^{\circ} \mathrm{C}$ at appropriate dilution, followed by incubation with the secondary antibody (against the species used for development of the primary antibody) tagged with a green fluorescent dye (Alexa Fluor 488) for $1 \mathrm{~h}$. After rinsing, the sections were again blocked using 5\% normal goat serum in 3\% BSA-TBS for 30 $\mathrm{min}$ at $37^{\circ} \mathrm{C}$ before adding the next primary antibody for a $1 \mathrm{~h}$ incubation at $37^{\circ} \mathrm{C}$, and then tagging with secondary antibody (against the species used to develop the primary antibody) tagged with a red fluorescent dye (Alexa Fluor 555). Finally, sections were counterstained with DAPI dye to stain nuclei by soaking slides in DAPI solution for $30 \mathrm{~min}$ at $37^{\circ} \mathrm{C}$. To minimize quenching of the signal, sections were stored in the dark during storage and staining and examined at the University of California-Los Angeles (UCLA) Confocal Microscopy Core using a Leica Confocal Microscope (SP2 1P-FCS). To eliminate bias, confocal micrographs were taken with closely matched planes and were performed blinded and with consultation with experts running the UCLA Confocal Microscopy Core. The micrographs were all of the stratum radiatum with the pyramidal neurons in full view in the upper left corner $(-3.0 \mathrm{~mm}$ bregma). The source of primary antibodies used for confocal is described in Chemicals, reagents, and antibodies, above and included antibodies to MAP2,
NR2B, P-MAP1B, and active GSK3 $\beta$ Y279 or the SMI-31 antibody. P-MAP1B was labeled with Alexa Fluor 488; SMI-31 was labeled using an Alexa Fluor 555 mouse IgG1 kit (catalog \#Z-25005; Zeon).

Additional sections were stained for tyrosine hydroxylase using the pAb to tyrosine hydroxylase (sc-14007; Santa Cruz Biotechnology) and evaluated by light microscopy. Stored slides with cryosections of mouse brain were removed from the $-80^{\circ} \mathrm{C}$ freezer, warmed to room temperature for $20 \mathrm{~min}$, and then steamed for $15 \mathrm{~min}$ in unmasking antigen solution from Vector Laboratories (H-3300). Sections were quenched in $0.6 \%$ hydrogen peroxide with methanol for $30 \mathrm{~min}$ at room temperature and washed 3 times with Tris buffer solution (TBS), pH 7.4. After treating sections with $0.3 \%$ Triton X-100 in $0.1 \mathrm{M} \mathrm{TBS,} \mathrm{pH} \mathrm{7.4,} \mathrm{for} 10 \mathrm{~min}$, sections were incubated with 5\% NGS containing 3\% BSA/TBS for $1 \mathrm{~h}$ at $37^{\circ} \mathrm{C}$ to reduce nonspecific staining. Then, the primary antibody $(1: 150$ dilution) was added and sections incubated overnight at $4^{\circ} \mathrm{C}$. Vector biotinylated goat anti-rabbit (BA-1000) antibody (1:1200) was used with $1.5 \%$ normal goat serum and 3\% BSA/TBS. Sections were incubated in secondary antibody, followed by Vectastain ABC Elite Standard Kit (PK6100; Vector Laboratories) for $1 \mathrm{~h}$ at $37^{\circ} \mathrm{C}$. Slides were developed using the Peroxidase/Diaminobezidiene Metal Enhance Substrate kit (catalog \#34065; Pierce). Images were acquired from an Olympus Vannox-T (AHBT) microscope with an Optronix Engineering LX-450A CCD video camera system onto a Macintosh computer via an averaging frame grabber (AG-5; Scion) and then analyzed with ImageJ.

Statistical analysis. Statistical analysis of biochemical data was performed with StatView 5.0 software. Differences among means were assessed by ANOVA, followed by Fisher's LSD or Tukey-Kramer post hoc tests to determine differences between preplanned comparisons. Analysis of behavioral data was done with SPSS version 21 statistical software package. For the hidden platform test, latencies and distances swam across the 4 swim trials per day were analyzed across the $5 \mathrm{~d}$ of testing. Then, a two-way repeated-measures ANOVA was used (treatment $X$ day/block), with the repeated measure being either latency or distance swam as the dependent variable. For probe trials and visible platform testing, the means are compared between groups via a one-way ANOVA; Fisher's LSD or Bonferroni's test was used for post hoc analyses.

\section{Results}

\section{Age-dependent behavioral deficits in Old tau KO mice compared with age-matched WT mice in the MWM}

To determine whether there is an age-dependent effect of loss of tau on spatial memory, we examined performance in the MWM of WT and aged-matched tau KO mice at different ages: young (2-3 month, data not shown), middle-aged (8-9-month-old), and aged (19-20-month-old). Swim speed averages were similar between the MKO and the middle-aged and old WT, and young $\mathrm{KO}$ mice, but slower in OKO mice (data not shown, $p<0.01$ ). Both latencies (Fig. 1A) and path length (Fig. 1B) are shown. OKO was the only group that did not show a significant negative regression with either latency or path (Fig. 1B). Repeatedmeasures two-way ANOVA (treatment $\times$ block) for escape latencies and path to a hidden platform during MWM acquisition revealed significant treatment and block effects $(p<0.01$; Fig. $1 A, B)$. Further analysis demonstrated that, compared with old WT, OKO showed higher latencies for block days 3, 4 ( $p<0.05)$, and $5(p<0.01$; Fig. $1 A)$, and higher path lengths at block $5(p<$ 0.05 ) and trends for longer paths on blocks 3 and 4 (Fig. $1 B$ ). However, both OKO and old WT groups included mice not finding the platform by the maximum time of $60 \mathrm{~s}$, so for these mice, the slower OKO would have shorter paths that could yield underestimation of their path deficits. There were no differences in latencies and path length between $\mathrm{MKO}$ and middle-aged WT (Fig. $1 A, B$, respectively). The OKO showed a significant increase in percentage path swam in the thigmotaxis zone $(15 \mathrm{~cm}$ from the wall) compared with all other groups (data not shown). 
A

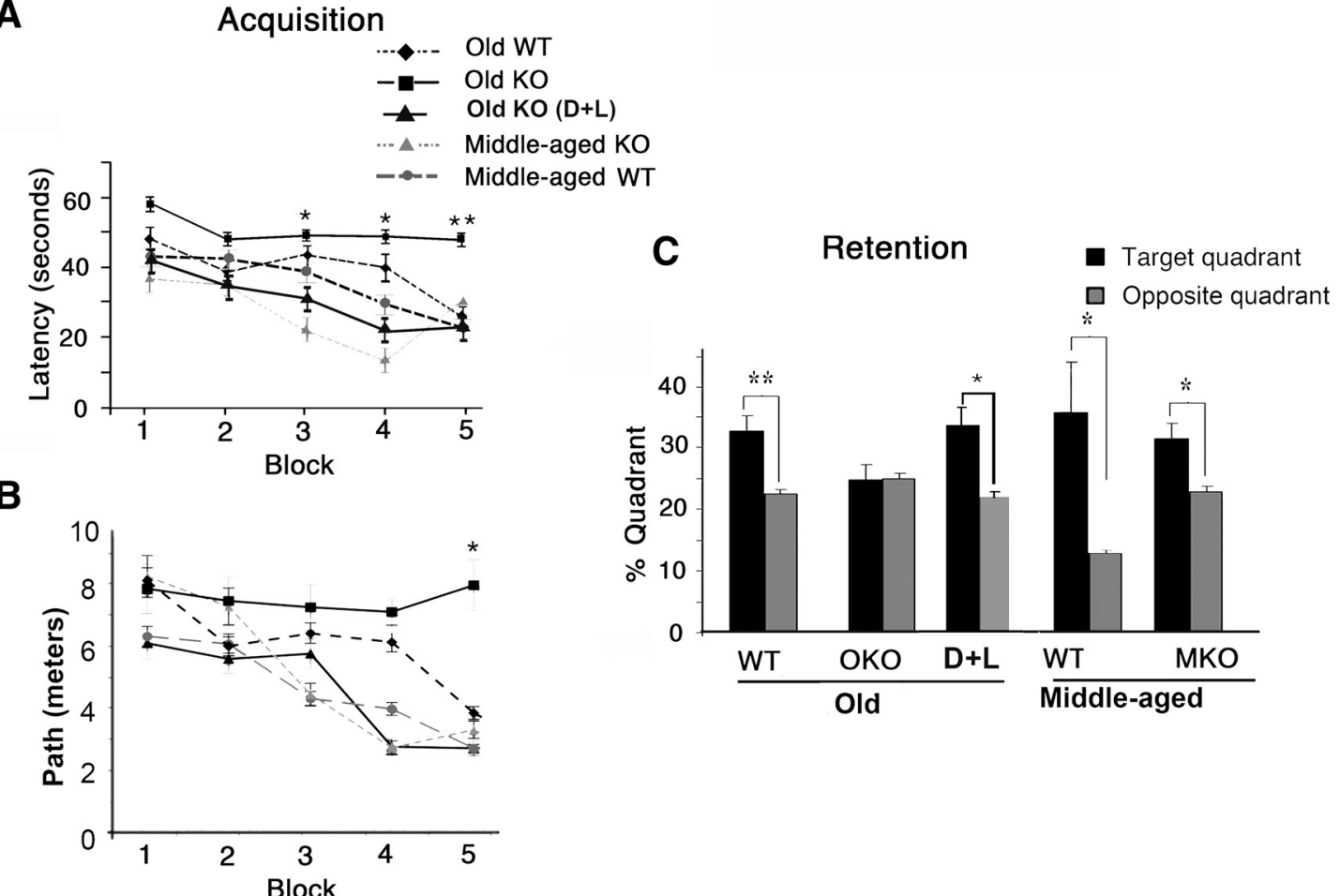

D

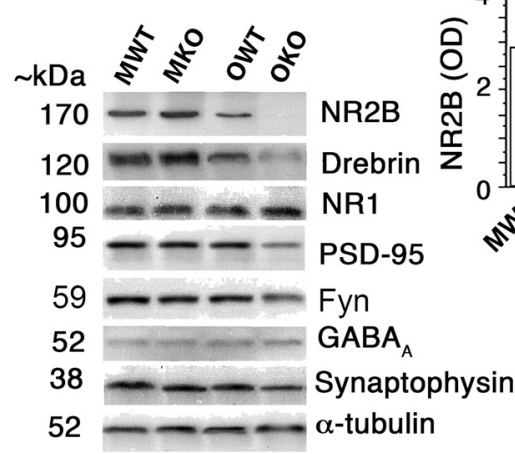

$\mathbf{F}$

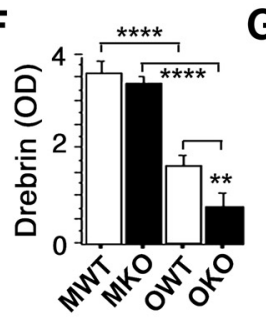

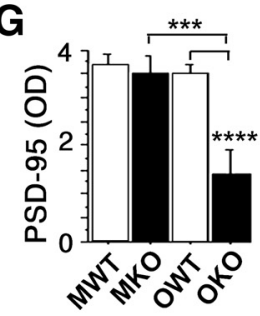
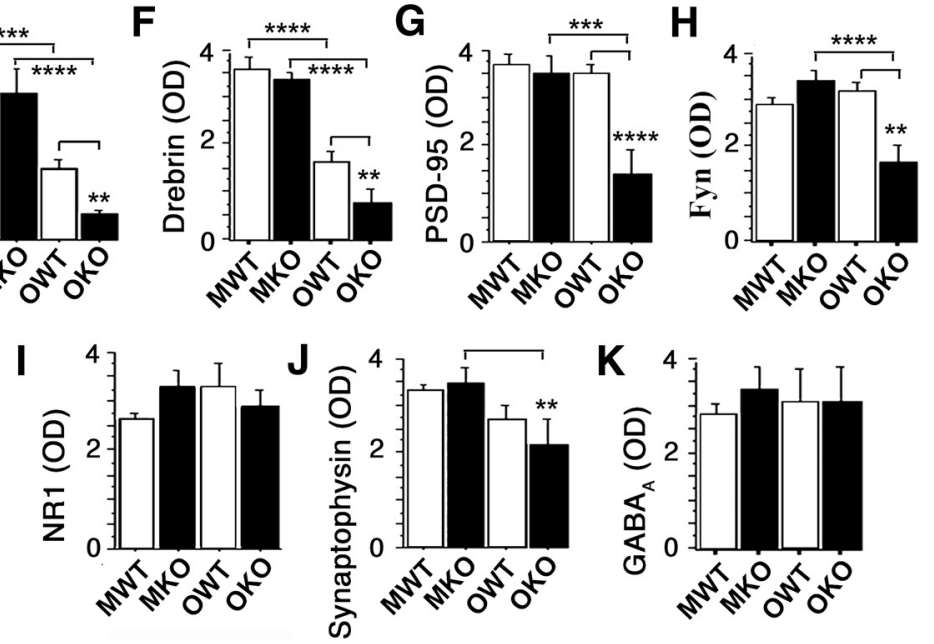

Figure 1. Spatial memory deficits and synapse loss in $0 K 0$ and correction by $\omega$-3 fatty acid DHA diets. Fourteen- to 15 -month-old 0 KO were fed with or without $0.6 \%$ DHA plus 500 ppm $\alpha$-lipoic acid $(D+\mathrm{L})$ for 5 months, and behavioral deficits were evaluated using the MWM. $\boldsymbol{A}, \boldsymbol{B}$, Learning curves for the mean escape latency $(\boldsymbol{A})$ and path $(\boldsymbol{B})$ to a hidden platform during acquisition $(20$ trials total over 5 blocks). ANOVA analyses showed significant treatment effects for latency $(\boldsymbol{A}, p<0.0001)$ and path $(\boldsymbol{B}, p<0.001)$, as well as a group $\times$ block interaction for both latency $(\boldsymbol{A}, p<0.001)$ and path $(\boldsymbol{B}, p<0.05)$. All groups showed a significant negative regression in path and latency $(p<0.05)$ except the OKO group, which showed no significant acquisition in either path or latency. Age-dependent impairment in performance was more pronounced in KO mice than WT mice. For example, Bonferroni's post hoc tests showed that OKO mice had longer latencies than MKO mice on days $1-5(p<0.001)$ and longer paths on days $3-5$, but in WT mice, age-dependent effects were less prominent. Compared with old WT, 0 K0 animals exhibited longer latencies on days $3,4(p<$ $0.05)$, and $5(p<0.01)$ and longer paths on day $5(p<0.05)$. In contrast, middle-aged WT mice performed similarly. However, diet improved performance in the $0 K 0$, because $0 K 0$ mice fed $D+L$ showed significantly shorter latencies on days $3-5(p<0.01)$ and shorter paths on days $1-5(p<0.001)$ and even outperformed old WT in latencies on days 3 and 4 and in path on day 5 ( $p<$ 0.05 ; Fig. $1 A$ and $B$ ). $C$, Mean percentage time spent in the target quadrant versus that spent in the opposite quadrant durig the probe trial. Paired $t$ tests for percentage time in the target compared with opposite quadrant for each group revealed a significant difference in the old WT $(p<0.01)$, D $+\mathrm{L} 0$ OKO $(p<0.05)$, middle-aged WT $(p<0.05)$, and MKO ( $p<0.05)$ groups, which was also significantly different from chance $(p<0.05)$. In contrast, untreated 0 KO displayed no preference for target quadrant in the probe trial. $D$, Representative WB illustrating levels of synaptic proteins NR2B, drebrin, NR1, PSD-95, Fyn, GABA $A_{A}$ and synaptophysin from hippocampal membrane lysis fractions of WT and tau K0 mice. $\alpha$-tubulin was used for normalization, but did not influence significance levels. $\boldsymbol{E}-\boldsymbol{H}$, Quantification of postsynaptic excitatory markers NR2B, drebrin, PSD-95, and Fyn revealed that all were significantly reduced in $0 K 0$ compared with old WT mice ( $p<0.01$ for NR2B, drebrin, and Fyn, $p<0.0001$ for PSD-95) or compared with MKO ( $p<0.0001$ for NR2B, drebrin, and Fyn, $\boldsymbol{E}, \boldsymbol{F}, \boldsymbol{H} ; \boldsymbol{p}<0.001$ for PSD-95, G). Synaptophysin showed age-dependent reduction in tau K0 mice $(p<0.01 ; I)$. WT mice only displayed age-dependent reduction of NR2B and drebrin. Compared with middle-aged WT mice, old WT mice had significant loss of NR2B $(p<0.001 ; \boldsymbol{E})$ and drebrin $(p<0.0001 ; \boldsymbol{F})$. I- $\boldsymbol{K}$, In contrast, quantification of NR1, synaptophysin, and GABA $\mathrm{A}_{\mathrm{A}}$ showed that there were no significant changes in $0 \mathrm{KO}$ either compared with WT mice $(p>0.05)$ or compared with MKO mice $(p>0.05)$, although synaptophysin trended down in OKO mice. 

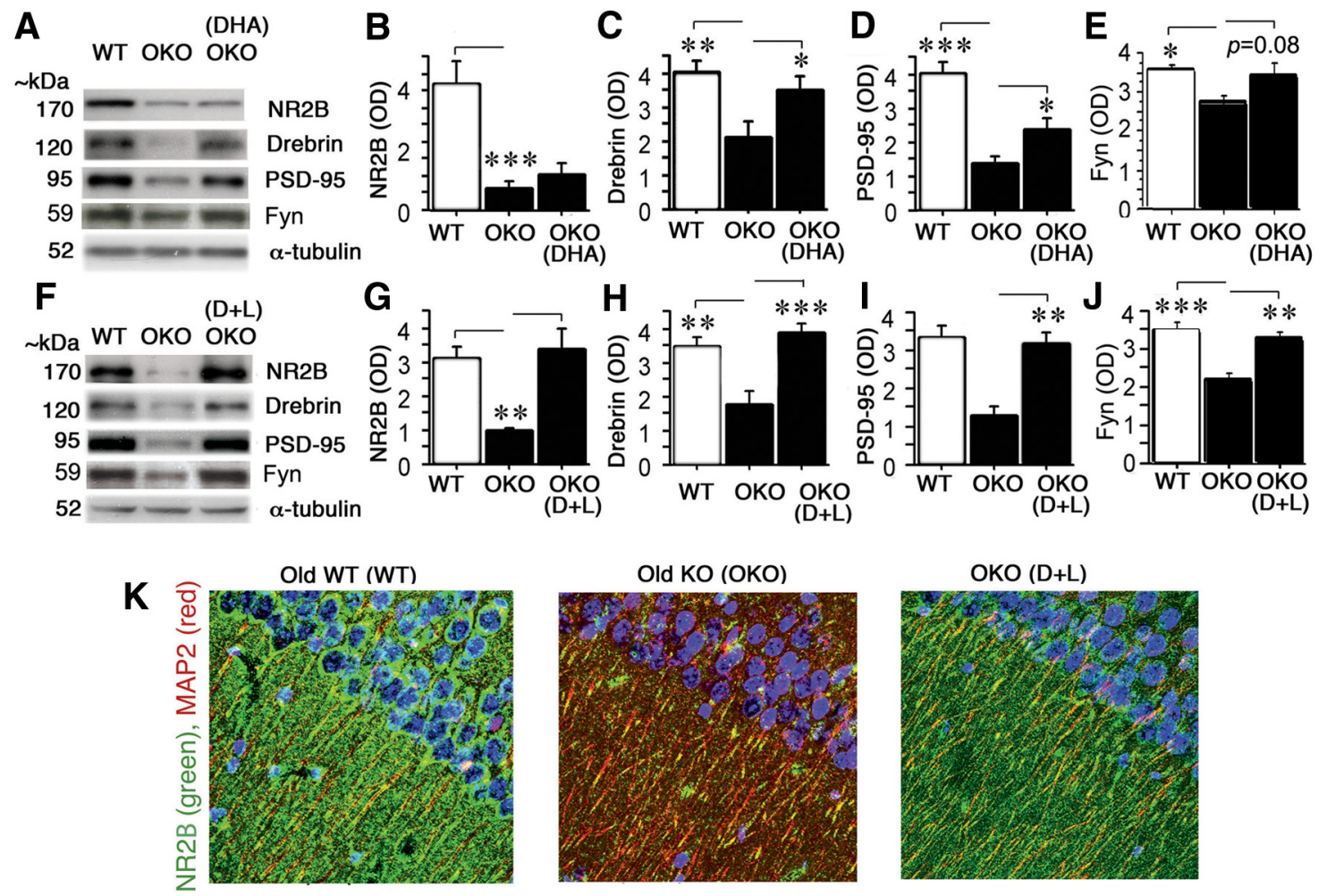

Figure 2. Dietary $\omega-3$ (n-3) fatty acid DHA-based diets significantly prevented the synaptic marker loss in OKO mice. Fourteen- to to 15 -month-old OKO were fed control diet, $0.6 \%$ DHA, or a combination of DHA with $500 \mathrm{ppm} \alpha$-lipoic acid $(\mathrm{D}+\mathrm{L})$ for 5 months $(n=9$ for control diet, $n=8$ for DHA and $\mathrm{D}+\mathrm{L})$ and then hippocampi were evaluated for excitatory synaptic proteins NR2B, drebrin, PSD-95, and Fyn by WB of membrane fractions or confocal microscopy. $\boldsymbol{A}-\boldsymbol{E}$, In OKO, although DHA did not affect OKO-dependent loss of NR2B $(p>0.05 ; A, B)$, it did significantly prevent the loss of excitatory synaptic markers PSD-95 $(p<0.05)$ and drebrin $(p<0.05 ; \boldsymbol{A}, \boldsymbol{C}, \boldsymbol{D})$ with a trend for Fyn $(p=0.08, \boldsymbol{A}, \boldsymbol{E})$ compared with untreated OKO mice. $\boldsymbol{F}$-J, Unlike DHA alone, the combination $\mathrm{D}+\mathrm{L}$ preserved NR2B and Fyn $(p<0.01 ; \boldsymbol{F}, \boldsymbol{G}, \boldsymbol{J})$, in addition to preventing the loss of drebrin $(p<0.001 ; \boldsymbol{H})$ and PSD-95 $(p<0.01 ; \boldsymbol{I})$ compared with untreated 0K0. The combination treatment efficacy for all synaptic markers was greater than with DHA alone. NR2B/MAP2 was also examined by confocal immunocytochemistry. $\boldsymbol{K}$, CA1 NR2B (green) was largely reduced in $0 K 0$ along intact dendrites of the stratum radiatum (MAP2, red) adjacent to CA1 neuronal nuclei (blue, DAPI) compared with WT mice, in which NR2B showed punctuate staining along MAP2-labeled CA1 dendrites. The OKO defect in NR2B staining appeared largely corrected by D $+\mathrm{L}$ diet.

Figure $1 C$ shows performance of different groups in the probe trial. One-way ANOVA analysis of the percentage time in target quadrant showed a significant treatment effect $(p<0.05)$. Paired $t$ test analysis showed that, except for the OKO, all groups spent more time in the target quadrant than chance $(p<0.05)$ and more time than in the opposite quadrant $(p<0.05)$.

After euthanizing the mice, we evaluated synaptic protein marker changes by WB in the hippocampus (Fig. $1 D-K$ ). Post hoc analysis of both NR2B and drebrin revealed age-dependent effects that were exacerbated by tau deletion. From middle aged to old, WT mice showed a 2 -fold reduction, whereas $\mathrm{KO}$ mice showed a 9-fold reduction $(p<0.0001$; Fig. $1 E, F)$. In contrast, only tau $\mathrm{KO}$ mice displayed age-dependent declines in PSD-95 $(p<0.001)$, Fyn $(p<0.0001)$, and synaptophysin $(p<0.01)$. Compared with aged WT mice, loss of tau showed a reduction of hippocampal excitatory synaptic components of NR2B $(p<$ $0.01)$, drebrin $(p<0.01)$, PSD-95 $(p<0.0001)$, and Fyn $(p<$ 0.01 ), but there were no significant differences between OKO and age-matched WT for NR1, synaptophysin, or the inhibitory synaptic marker $\mathrm{GABA}_{\mathrm{A}}(p>0.05$; Fig. $1 E-K)$.

Dietary $\mathrm{D}+\mathrm{L}$ attenuate MWM deficits and synaptic marker loss in OKO, whereas DHA alone attenuates synaptic marker loss

OKO mice were fed a diet with $\mathrm{D}+\mathrm{L}$ and exhibited improved MWM performance relative to untreated OKO mice. Post hoc analysis showed significant reductions in latency and path (days
$1-5)$ between $\mathrm{OKO}$ and $\mathrm{OKO}(\mathrm{D}+\mathrm{L})$, and outperformed old WT in latencies in blocks 3-5 and in path in block $5(p<0.05$; Fig. $1 A, B)$. Post hoc analysis of probe retention data demonstrated that unlike the OKO, but like the $\mathrm{WT}$, the $\mathrm{D}+\mathrm{L}$ group showed a preference for target quadrant $(p=0.05)$ relative to other quadrants (Fig. 1C). Thigmotaxis defects were fully corrected by $\mathrm{D}+\mathrm{L}$ (data not shown).

Synaptic protein marker loss was assessed in hippocampal extracts by semiquantitative analysis of density of WBs in 14- to 15 -month-old OKO mice supplemented with $0.6 \%$ DHA or DHA and $500 \mathrm{ppm} \alpha$-lipoate acid (D+L) or placebo control (Fig. $2 A-J)$. To enable comparisons between blots, each blot assessing one diet also contained the same samples from the untreated OKO and old WT mice. Mulitvariate analysis of synaptic variables and Fyn in the DHA study showed a significant treatment effect $(p<0.01)$. Post hoc analysis showed that DHA failed to affect the tau-deletion-associated loss of NR2B in the OKO ( $p>$ 0.05 ; Fig. $2 A, B)$, but prevented the loss of drebrin $(p<0.05$; Fig. $2 A, C)$ and attenuated the loss of PSD-95 ( $p<0.05$; Fig. $2 A, D)$. There was a nonsignificant trend to restore Fyn $(p=0.08$; Fig. $2 A, E)$.

Mulitvariate analysis of synaptic variables and Fyn in the D+L study also showed a significant treatment effect (Fig. 2F-J). Post hoc analysis showed that the $\mathrm{D}+\mathrm{L}$ combination has similar effects on synaptic proteins as DHA alone, preventing the OKOassociated loss of drebrin $(p<0.001$; Fig. $2 F, H)$ and fully protecting for loss of NR2B ( $p<0.01$; Fig. $2 F, G)$, PSD-95 ( $p<0.01$; 
A

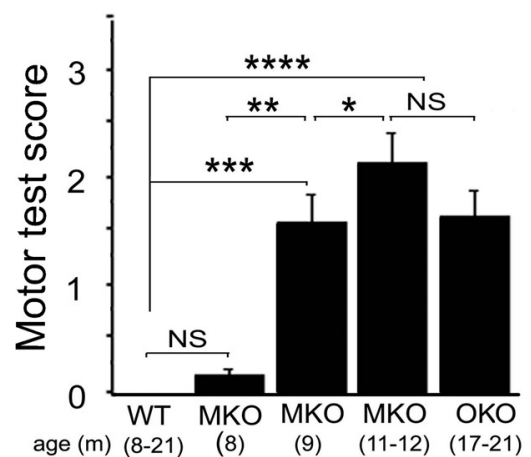
age $(m)(8-21) \quad(8)$
(DHA)

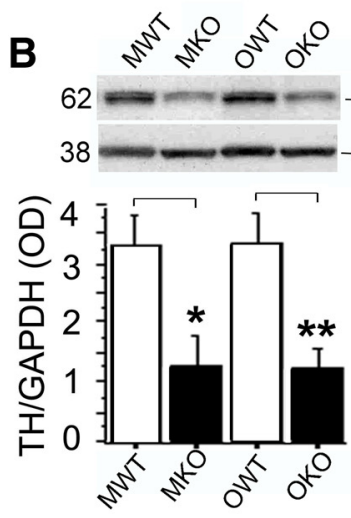

E

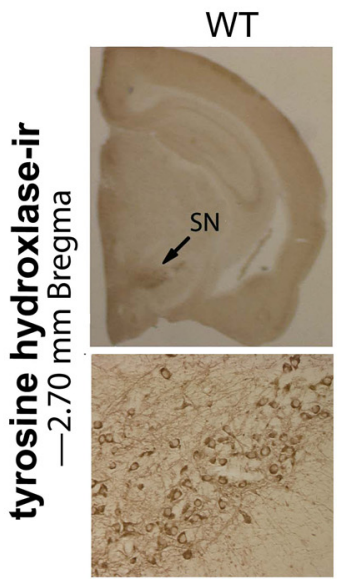

C

GAPDH -

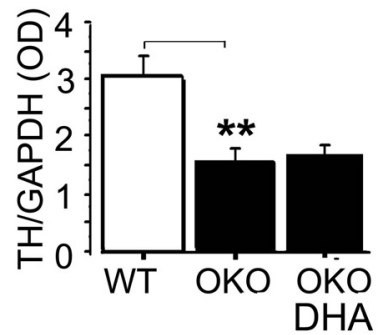

OKO

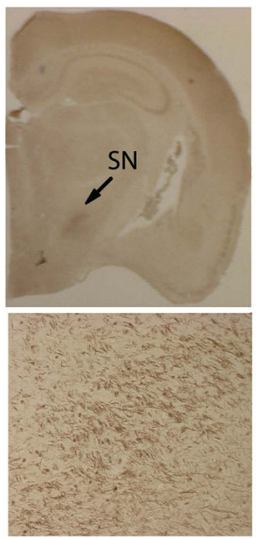

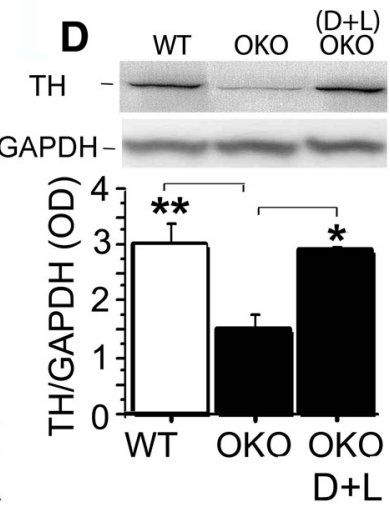

$\mathrm{OKO}(\mathrm{D}+\mathrm{L})$

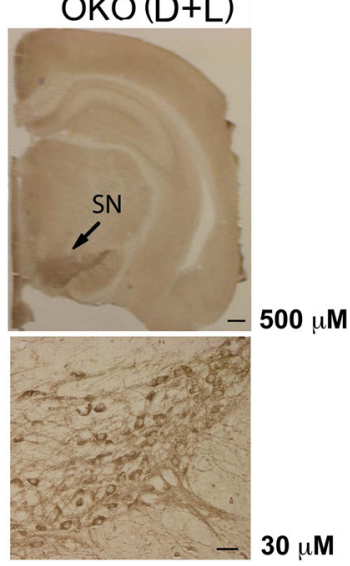

Figure 3. Motor deficits and loss of TH appeared in MKO mice without further decline in $O K O$, but $D+L$ diet prevented the loss of TH in OKO. A, Ledge, gait, hindlimb clasping, and kyphosis motor tests were conducted in 8- to 21-month-old tau KO mice ( $n=$ 8 for 8 - to 21-month-old WT mice, $n=5$ for 8-month-old tau KO mice, $n=6$ for 9-month-old tau K0 mice, $n=8$ for 11- to 12-month-old tau KO mice, $n=9$ for 17- to 21-month-old tau KO mice) and showed both motor coordination and motor deficits in 9-month-old tau MKO compared with age-matched WT mice $(p<0.001)$. The motor deficits in tau KO mice significantly progressed from 8 to 9 months $(p<0.01)$ and from 9 to 11-12 months $(p<0.05)$, but did not further decline in 17- to 21-month-old OKO mice $(p>0.05)$. $\boldsymbol{B}$, Consistent with motor coordination deficits, TH was also significantly decreased in substantia nigra from both MKO $(p<0.05)$ compared with middle-aged WT mice and OKO compared with old WT mice, but was improved by $\mathrm{D}+\mathrm{Ldiet}$ in $\mathrm{OKO}(p<0.05 ; \boldsymbol{D})$, not by DHA alone $(p>0.05 ; C)$, indicating that motor deficits did not simply correlate with MWM and synaptic deficits. $E$, Immunohistochemistry staining revealed the loss of TH in $0 K 0$ mice and restored by $D+L$ diet.

Fig. $2 F, I)$, and Fyn $(p<0.01$; Fig. $2 F, J)$. That is, like DHA alone, $\mathrm{D}+\mathrm{L}$ prevented loss of drebrin, but, unlike $\mathrm{DHA}$ alone, $\mathrm{D}+\mathrm{L}$ also fully protected from loss of PSD95, Fyn, and NR2B. Figure $2 K$ depicts confocal micrographs that parallel the WB findings of extensive loss of NR2B. Staining revealed that the immunopositive dendrites observed in aged WT mice (Fig. $2 K$, left) in the stratum radiatum (green) were diminished in $\mathrm{OKO}$ mice (Fig. $2 K$, middle), although MAP2-positive dendrites (red) were still present in $\mathrm{OKO}$ mice. The micrograph on the right in Figure $2 K$

shows that $\mathrm{D}+\mathrm{L}$ essentially restored NR2B immunoreactivity along dendrites to the level found in WT.

Motor deficits in middle-aged KO mice without further decline in old KO mice Next we assessed the progression of motor deficits (ledge, gait, motor coordination, hindlimb clasping, and kyphosis) in 7- to 21-month-old WT and KO mice using additional animal groups, with the sum score representing a global score for motor function (Fig. 3A). No deficits were observed in WT mice (all ages; Fig. 3A), 2to 3-month-old $\mathrm{KO}$ mice, or 7-month-old KO mice (data not shown, motor score $=$ 0 ), and scores for 8-month-old $\mathrm{KO}$ mice were not significantly different from the age-matched WT mice. However, by 9 months of age, significant mild motor deficits were apparent in $\mathrm{KO}$ mice (motor score $=2$ of a maximum score of 12$)$ that further progressed at 11 to 12 months of age (motor score $=3$ ), but there was no detectable further declines in motor impairment at 17 to 21 months of age (motor score $=2.5$; Fig. $3 A$ ). The motor deficits were mainly observed in ledge, gait, and motor coordination and kyphosis motor tests with less hindlimb clasping impairment. Despite mild motor deficits in the $\mathrm{MKO}, \mathrm{MKO}$ showed no MWM deficits (Fig. 1A-C), and their mild motor impairment did not affect their ability to swim or their swimming speed (data not shown).

\section{$\mathrm{D}+\mathrm{L}$ diet, but not $\mathrm{DHA}$ alone, prevents the loss of tyrosine hydroxylase in old KO mice}

Consistent with motor coordination deficits, tyrosine hydroxylase ( $\mathrm{TH}$ ) was also significantly decreased in the substantia nigra in $\mathrm{MKO}$ compared with middle-aged WT mice $(p<0.05)$ and in OKO compared with old WT mice $(p<0.01$; Fig. $3 B)$. The $\mathrm{D}+\mathrm{L}$, but not $\mathrm{DHA}$ alone, diet restored $\mathrm{TH}$ levels in the OKO ( $p<0.05$; Fig. 3C,D). Immunohistochemical staining paralleled the WB results, showing that the loss of $\mathrm{TH}$ in $\mathrm{OKO}$ was prevented by $\mathrm{D}+\mathrm{L}$ diet (Fig. $3 E)$. Importantly, $\mathrm{TH}$ and motor deficits emerged in middle-aged $\mathrm{KO}$, but were not accompanied by MWM or hippocampal synaptic deficits.

Compensatory responses in MAP1 and MAP2 to tau deletion in middle-aged $\mathrm{KO}$, but not in old $\mathrm{KO}$ mice

Because the neuronal microtubule network is maintained by MAPs (tau, MAP1A, MAP1B, and MAP2), which similarly promote microtubule assembly and stability, we then tested whether tau LOF can be compensated by activity of other MAPs in tau KO mice by evaluating MAP1A (enriched in dendritic compared with axonal), MAP1B (axonal or dendritic), and MAP2 (soma- 
A

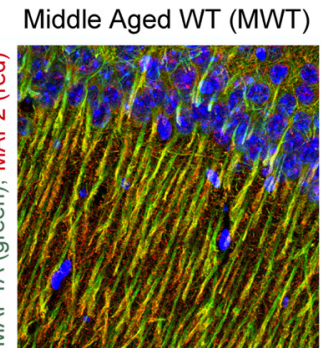

B

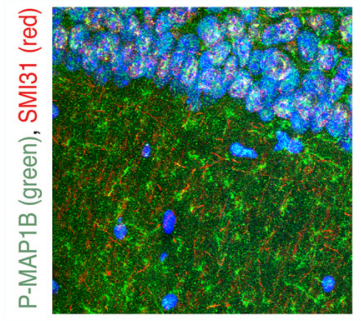

Middle Aged KO (MKO)
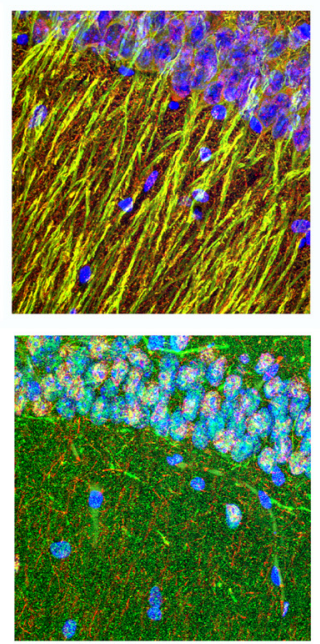

Old WT (OWT)
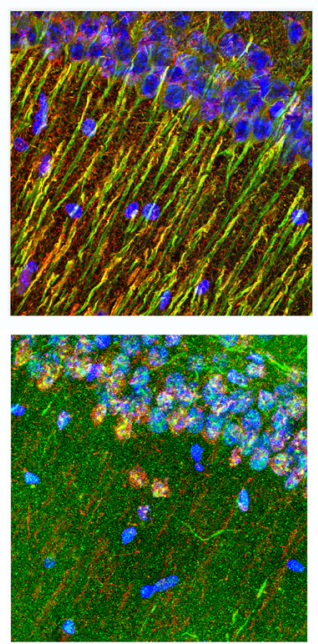

Old KO (OKO)
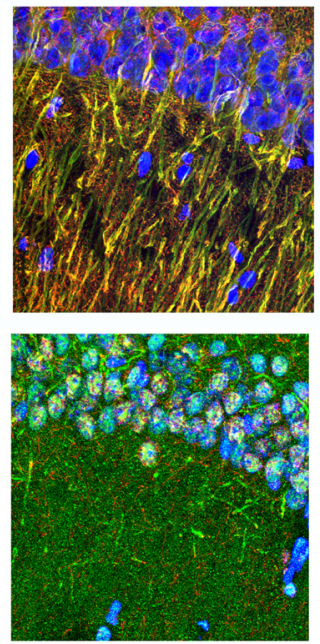

C TBS

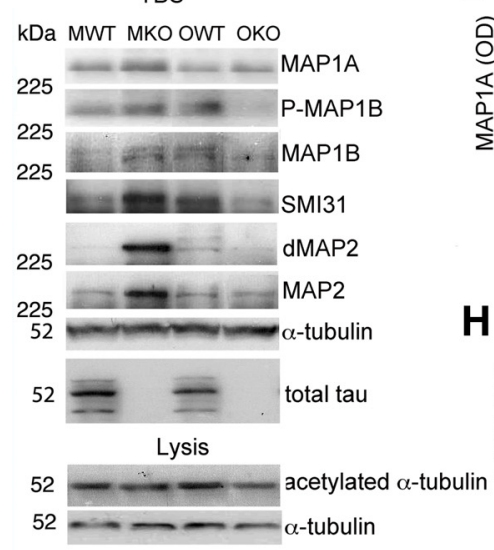

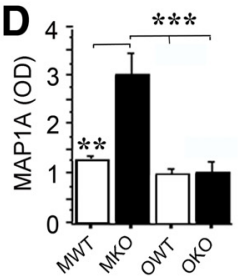

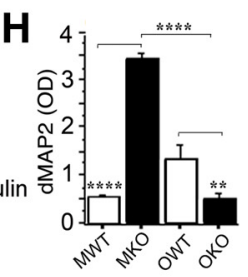

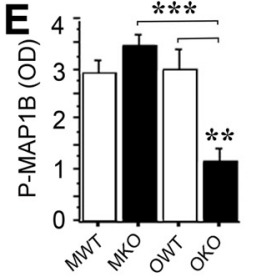

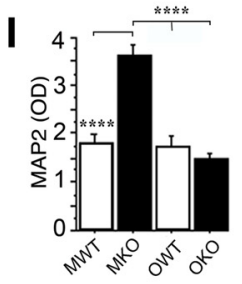

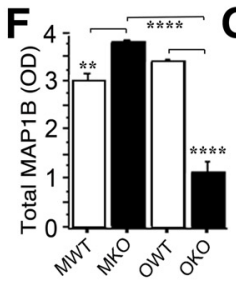
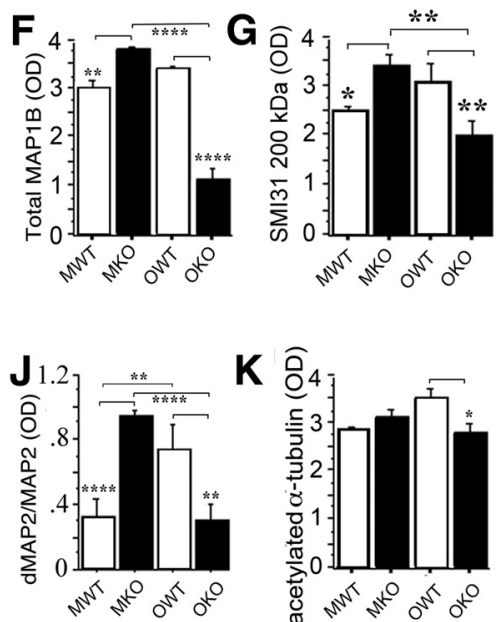

K

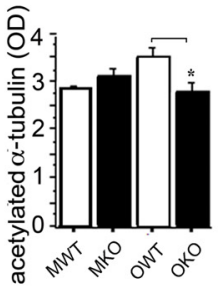

Figure 4. Loss of tau function was partially compensated by other microtubule-associated proteins MAP1 and MAP2, with microtubule stability maintained in middle-aged, but not in old tau KO mice. $A$, Confocal microscopy showing that the intensity and linear staining of MAP1A was higher in MKO compared with middle-aged and old WT and OKO. B, In the middle-aged WT mice, P-MAP1B was distributed in a well organized, punctate pattern in the hippocampal CA1 subfield, but in MKO, OKO, and old WT mice, this structure disappeared and presented ropelike structures. A less specific anti-P-MAP1B monoclonal antibody, SMI-31, was used for counterstaining to also visualize phospho-neurofilaments (red). C, Representative WB for protein quantification of $\boldsymbol{D}-\boldsymbol{K}$ illustrated levels of MAP1A/B, MAP2, SMI31, acetylated $\alpha$-tubulin, and total tau from hippocampus of WT and tau KO mice. Total tau was not detected in tau K0 mice. D, WB analysis of total MAP1A revealed elevated levels of MAP1A in MKO compared with middle-aged WT mice $(p<0.01)$ and old WT mice $(p<0.001)$ or OKO $(p<0.001)$. E, P-MAP1B was decreased in 0K0 compared with old WT mice $(p<$ $0.01)$ or MKO mice $(p<0.001)$. F, Total MAP1B was increased in MKO compared with middle-aged WT mice $(p<0.01)$ and was decreased in $0 K 0$ compared with old WT mice $(p<0.0001)$ or MKO mice $(p<0.0001)$. G, SMI31 was increased in MKO compared with middle-aged WT mice $(p<0.05)$ and was reduced in 0KO compared with old WT mice $(p<0.01)$ or MK0 mice $(p<0.01)$. $\boldsymbol{H}$, A polyclonal antibody recognizing dephospho-MAP2, but not MAP2 phosphorylated at the C-terminal JNK-sensitive site, was used to identify active MAP2 and gave significant increases in MKO compared with middle-aged WT mice $(p<0.0001)$ and decreases in OKO compared with old WT mice $(p<0.01)$ or MKO mice $(p<0.0001)$. $I$, Total MAP2 was similar in 0K0 and WT, but was increased in MKO compared with middle-aged WT mice $(p<0.0001)$ or OKO mice $(p<0.0001)$. J, The ratio of dephospho-MAP2 to MAP2 was also significantly increased in MK0 compared with middle-aged WT mice $(p<0.0001)$ and decreased in OKO mice compared with old WT mice $(p<0.01)$ or MKO mice $(p<0.0001)$. $K$, Acetylated $\alpha$-tubulin was significantly reduced in OKO compared with old WT mice $(p<0.05)$, whereas MKO mice showed no changes compared with middle-aged WT mice, suggesting that compensation of MAPs in MKO promoted microtubule stability.

todendritic) levels and their phosphorylation (Fig. 4A-K). Like tau, MAP1B and MAP2 can be hyperphosphorylated at microtubule-binding sites by "tau kinases," which inactivate MT binding-dependent activity. These MAPs are also abnormally phosphorylated in $\mathrm{AD}$, but, unlike tau, they do not form insoluble aggregates (Nieto et al., 1989; Hasegawa et al., 1990). Confocal microscopy showed that the staining intensity of MAP1A was higher in $\mathrm{MKO}$ compared with middle-aged and old WT and OKO, which is consistent with hyperactivation (Fig. $4 B$ ). Sections were counterstained with SMI-31 antibody (Fig. $4 B$, red), an antibody recognizing P-MAP1B sites and related sites in neurofilaments (Johnstone et al., 1997; Goold et al., 1999; Trivedi et al., 2005).

Levels of MAP1A, P-MAP1B, total MAP1B, SMI31, dMAP2, MAP2, dMAP2/MAP2, and acetylated $\alpha$-tubulin were measured by WB. One-way ANOVA post hoc analysis showed that, in WT mice, there were no changes between middle-aged mice and aged mice except for age-dependent increases of dMAP2 normalized to total MAP2 $(p<0.01$; Fig. $4 J)$. Compared with middle-aged WT mice, MKO showed clear increases in MAP1A $(p<0.01)$, dMAP2 $(p<0.0001)$, MAP2 $(p<0.0001)$, and dMAP2/MAP2 $(p<0.0001)$ and small increases in total MAP1B $(p<0.01)$ and SMI31 $(p<0.05)$, but no significant changes in P-MAP1B or acetylated $\alpha$-tubulin (Fig. $4 D-K$ ).

In aged mice, relative to old WT mice, OKO showed large reductions in P-MAP1B $(p<0.01)$, total MAP1B $(p<0.0001)$, and dMAP2/MAP2 $(p<0.01)$, as well as smaller reductions in SMI31 $(p<0.01)$, dMAP2 $(p<0.01)$, and acetylated tubulin $(p<0.05)$, a marker of microtubule stability that is markedly 

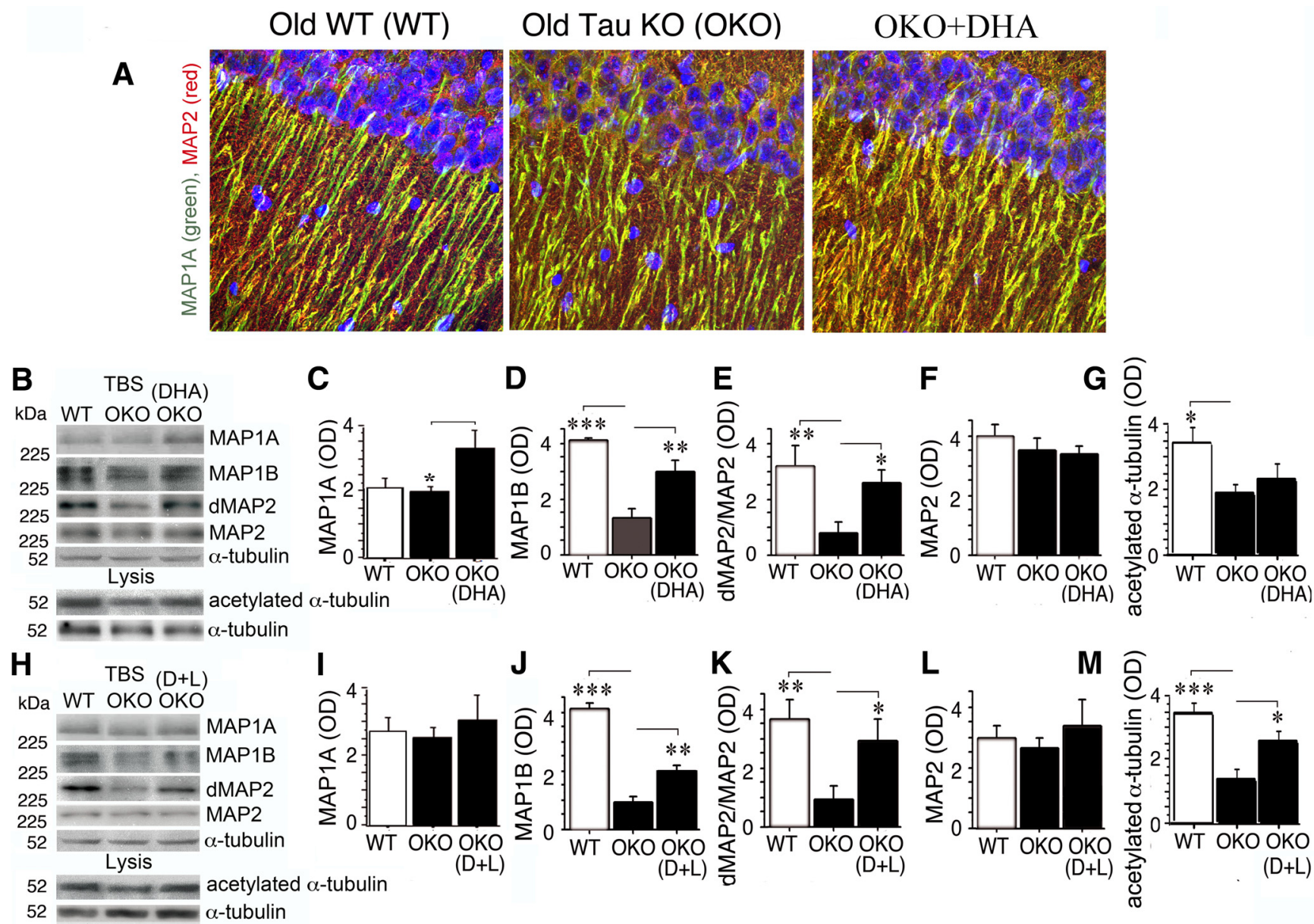

Figure 5. DHA-supplemented diets partially rescued MAP1A, MAP1B, and MAP2 deficits and microtubule stability in OKO. $A$, Confocal microscopy demonstrated that DHA diet increased high staining intensity of MAP1A ( $g r e e n$ ) in the dendritic field of the hippocampal CA1 (stratum radiatum) of OKO relative to OKO on control diet so that it better resembled the pattern seen in WT mice. $\boldsymbol{B}-\boldsymbol{M}$, WB analysis showed that DHA $(p<0.05 ; \boldsymbol{B})$, but not $\mathrm{D}+\mathrm{L}(p>0.05 ; \boldsymbol{I})$ diet significantly increased MAP1A in 0K0 compared with mice on control diet. Both DHA and D $+\mathrm{L}$ partially restored the loss of total MAP1B in $0 K 0(p<0.01 ; \boldsymbol{D}, \boldsymbol{J})$. Dephospho MAP2, specific for active MAP2, was also significantly elevated by both treatments $(p<0.05 ; \boldsymbol{E}, \boldsymbol{K})$, whereas total MAP2 did not change $(p>0.05 ; \boldsymbol{F}, \boldsymbol{L})$. Acetylated $\alpha$-tubulin was significantly reduced in $0 \mathrm{KO}(p<0.05, \mathbf{G} ; p<0.001, \boldsymbol{M})$ from two independent animal experiments with different groups raised at different times, whereas the reduction of acetylated $\alpha$-tubulin was significantly improved by $\mathrm{D}+\mathrm{L}(p<0.05 ; \boldsymbol{H}, \boldsymbol{M})$, but not by DHA alone $(p>0.05 ; \boldsymbol{B}, \boldsymbol{G})$.

reduced in neurofibrillary tangle-bearing neurons in $\mathrm{AD}$ (Hempen and Brion, 1996); however, there were no changes in MAP1A or MAP2 in OKO relative to old WT (Fig. $4 D-K)$. In contrast, MAP1A $(p<0.001)$ and total MAP2 $(p<0.0001)$ were reduced in OKO compared with MKO. Total MAP2 was unaltered between OKO and old WT mice, but increased in MKO, a possible compensatory change in the younger tau $\mathrm{KO}$ that is lost with aging $(p<0.0001 ;$ Fig. $4 I)$. The ratios of dephospho-MAP2 to MAP2 were also significantly decreased in OKO compared with old WT $(p<0.01)$ or MKO $(p<0.0001$; Fig. $4 J)$. Collectively, these results show an age-related loss of the active MAPs believed to compensate for loss of tau.

\section{DHA supplements rescued microtubule-stabilizing MAP1 and MAP2 in old KO mice}

Consistent with previous reports of DHA reducing phosphorylation of the MAP tau, supplementing diets with DHA or D $+\mathrm{L}$ also protected against MAP2 hyperphosphorylation in OKO (Fig. 5). Similar to the WB analysis described in Figure 4, confocal immunocytochemistry revealed no changes in MAP1A immunostaining (Fig 5, green) in aged mice comparing old WT and $\mathrm{KO}$, but DHA alone increased MAP1A immunostaining, increasing colocalization with dendritic MAP2 in OKO (Fig 5A, red). These findings were similar to the WB analysis (Fig. $5 B, C$ ). WB analysis also demonstrated that DHA significantly preserved the agedependent loss of hippocampal of MAP1B $(p<0.01)$, dMAP2/ MAP2 $(p<0.05)$ but did not protect from loss of acetylated $\alpha$-tubulin (Fig. 5D,E,G), P-MAP1B or SMI31 ( $p>0.05$, data not shown). Similarly, D $+\mathrm{L}$ supplements also significantly preserved the loss of total MAP1B ( $p<0.01$; Fig. $5 H, J)$ and dephosphorylated MAP2/MAP2 in OKO $(p<0.05$; Fig. $5 H, K)$, but not phosphorylated MAP1B or SMI31 ( $p>0.05$, data not shown). Unlike DHA alone, $\mathrm{D}+\mathrm{L}$ did not increase MAP1A. (Fig. $5 I$ ). There were no treatment effects on total MAP2 in OKO $(p>0.05$; Fig. $5 F, L)$. Reduction of acetylated $\alpha$-tubulin in OKO was partially restored by $\mathrm{D}+\mathrm{L}(p<0.05$; Fig. $5 \mathrm{H}, \mathrm{M})$, but not by DHA treatment alone $(p>0.05$; Fig. $5 B, G)$. This is consistent with synaptic marker results shown in Figure 2, which indicate that $\mathrm{D}+\mathrm{L}$ was more protective than DHA alone.

Tau deletion increases JNK activation, but reduces GSK3 $\beta$ in aged mice

Multiple protein kinases phosphorylate tau, MAP1, and MAP2, including JNK, GSK3 $\beta$, ERK, and CDK5 (Avíla et al., 1994; Reynolds et al., 2000; Sánchez et al., 2000a). To test whether inactivating site phosphorylation of MAP1B and MAP2 responds to 

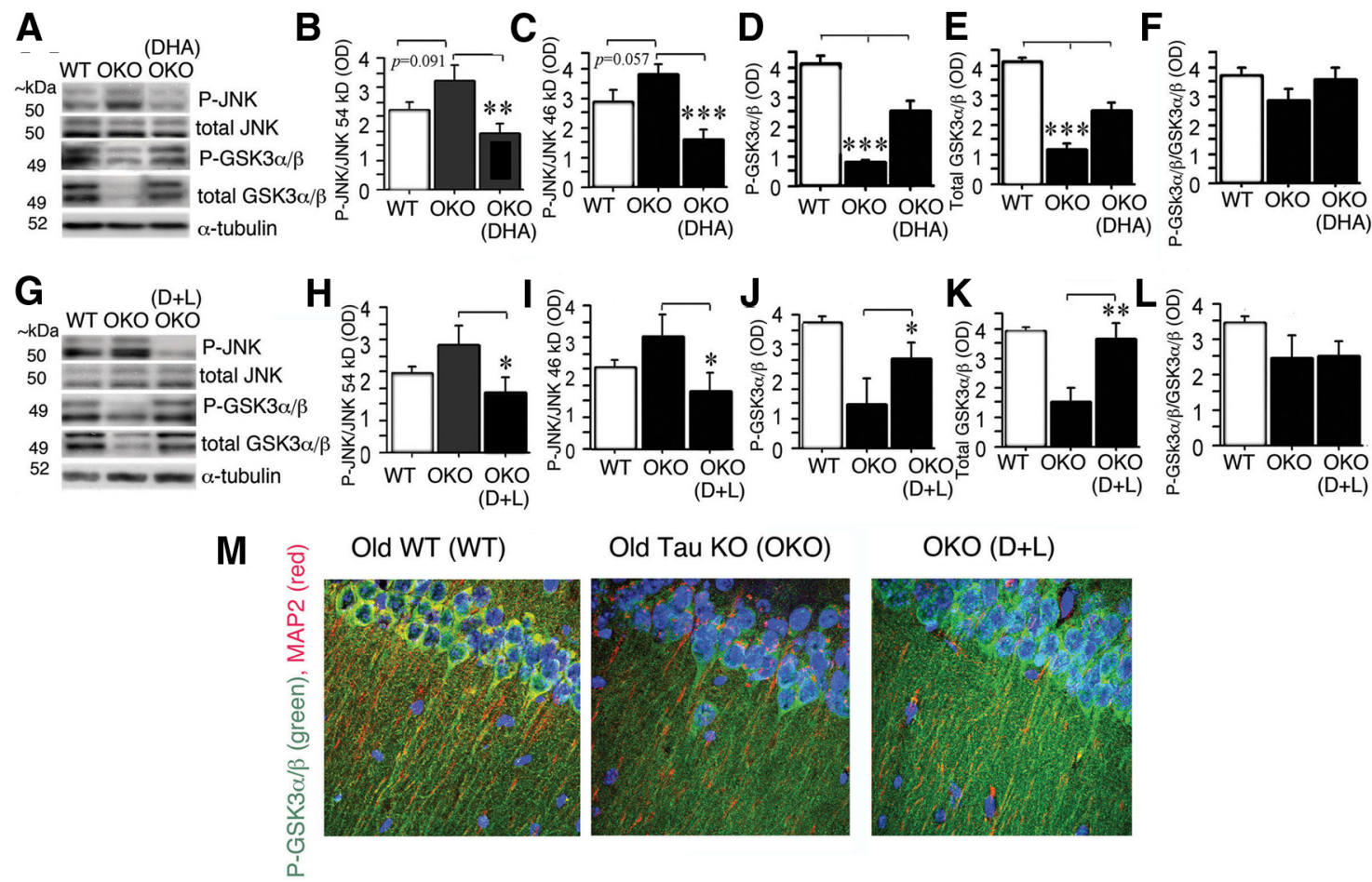

Old Tau KO (OKO)

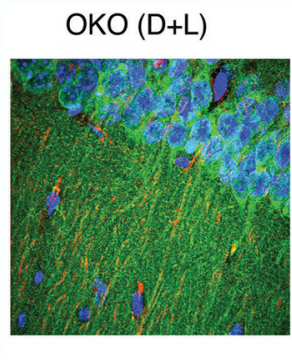

Figure 6. OKO showed hyperactivation of JNKs and loss of total GSK3 $\beta$, effects that were restored by both dietary DHA-based supplements. $A-C$, WB analysis revealed a strong trend for an increase in both P-JNK1 at $46 \mathrm{kDa}$ size $(p=0.057)$ and P-JNK2,3 at $54 \mathrm{kDa}$ size $(p=0.091)$ in $0 K 0$ versus WT mice, whereas DHA significantly reduced P-JNK1 $(p<0.001 ; A, C)$ and P-JNK2,3 $(p<$ $0.01 ; \boldsymbol{A}, \boldsymbol{B})$ in 0 KO. $\boldsymbol{D}-\boldsymbol{F}$, In contrast, both active P-GSK3 $\alpha / \beta$ (Y279; $\alpha$ upper band, $\beta$ lower band) and total GSK3 $\alpha$ and GSK $\beta$ showed significant decreases in $0 K 0(p<0.001 ; A, D, E)$, whereas the ratio of P-GSK3 $\beta$ to total GSK3 $\beta$ remained similar between the groups $(\boldsymbol{F})$. DHA restored or prevented the loss of both P-GSK3 $\alpha / \beta$ and total GSK3 $\alpha / \beta$ in aged tau K0 mice $(p<0.001 ; A, D, E)$. G- $\boldsymbol{L}$, $\mathrm{D}+\mathrm{L}$ restored JNK and GSK to WT levels, reducing P-JNK1 $(46 \mathrm{kDa}, p<0.05 ; \mathbf{G}, \mathbf{I})$ and P-JNK2,3 $(54 \mathrm{kDa}, p<0.05 ; \mathbf{G}, \boldsymbol{H})$ and increasing P-GSK3 $\beta(p<0.05 ; \boldsymbol{G}, \boldsymbol{J})$ and total GSK3 $\beta(p<0.01 ; \boldsymbol{G}$, $K$ ) compared with untreated OKO on the standard diet. The ratio of P-GSK3 $\beta$ to GSK3 $\beta$ did not change with either treatment $(p>0.05 ; F, L)$. $M$, Confocal analysis with active P-GSK3 $\alpha / \beta$ (green) and MAP2 (red) in OKO, WT, and MKO showing that $D+L$ treatment restored the loss of GSK3 $\alpha / \beta$ in CA1 perikarya of OKO.

specific kinase changes in OKO, we initially investigated JNK and GSK3, both widely implicated in pathological phosphorylation of NFT (Lagalwar et al., 2006). We observed a strong trend for increased P-JNK1 (46 kDa, $p=0.057)$ and P-JNK2/3 (54 kDa, $p$ $=0.091$; Fig. $6 A-C)$ in OKO compared with old WT mice. In contrast, both active P-GSK $3 \alpha / \beta$ and total GSK $3 \alpha / \beta$ showed significant decreases in OKO $(p<0.001$; Fig. $6 A, D, E)$. Despite the losses in GSK3, the P-GSK $3 \alpha / \beta$ to total GSK3 $\alpha / \beta$ ratio was not different between groups (Fig. $6 F$ ). Consistent with WB data, confocal labeling revealed a loss of $\mathrm{P}-\mathrm{GSK} 3 \alpha / \beta$ in $\mathrm{CA} 1$ of $\mathrm{OKO}$ compared with other groups (Fig. 6M).

\section{DHA-supplemented diets inhibited JNKs but elevated GSK3 in old $\mathrm{KO}$ mice}

Next we examined treatment impact on JNK kinases because earlier studies reported dietary DHA reduced $\mathrm{A} \beta, \mathrm{P}$-tau and $\mathrm{P}-\mathrm{JNK}$ in the triple transgenic AD model, $3 \mathrm{xTg}$-AD mice (Ma et al., 2009). Results showed that, in our OKO lacking $A \beta$ or tau accumulation, DHA-treated mice showed significantly reduced P-JNK1 (46 kDa, $p<0.001$; Fig. 6A, C) and P-JNK2/3 (54 kDa, $p<0.01$; Fig. $6 A, B)$ compared with untreated OKO. Combined $\mathrm{D}+\mathrm{L}$ also reduced P-JNK1 $(p<0.05$; Fig. $6 G, I)$ and P-JNK2/3 $(p<0.05$; Fig. $6 G, H)$ in $\mathrm{OKO}$.

In contrast, $\mathrm{P}-\mathrm{GSK} 3 \alpha / \beta$ and total GSK $3 \alpha / \beta$ were only partially restored by treatment with both DHA $(p<0.001$; Fig. $6 A, D, E)$ and $\mathrm{D}+\mathrm{L}(p<0.05$ for $\mathrm{P}-\mathrm{GSK} 3 \alpha / \beta, p<0.01$ for GSK3 $\beta$; Fig. $6 G, J, K)$. The ratio of P-GSK $3 \alpha / \beta$ to total GSK $3 \alpha / \beta$ was not altered by the treatment $(p>0.05$; Fig. $6 F, L)$, suggesting preservation of total GSK3-enriched excitatory synapses rather than a regulatory change in constitutively activated GSK3. ICC also confirmed that both DHA (data not shown) and D $+\mathrm{L}$ preserved or restored active GSK3 $\alpha / \beta$ in OKO (Fig. $6 M$ ).

\section{Discussion}

Tau deletion led to MWM and hippocampal synaptic protein deficits, only in very old mice, whereas motor deficits and reductions in substantia nigral $\mathrm{TH}$ occurred at middle age without notable progression. Tau deletion in OKO not only reduced excitatory synaptic markers, but also reduced active forms of other MAPs, implicating the collective loss of functional MAPs and acetylated tubulin in synaptic deficits. In contrast, at middle age, tau deletion resulted in large increases in MKO hippocampal MAP1A and MAP2, suggesting protective, compensatory roles. Dietary D+L not only corrected motor deficits and TH deficiency, but also age-dependent deficits in OKO MAPs and synaptic proteins. Therefore, prevention of age-dependent loss of functional MAPs that compensated for loss of tau function may limit age-dependent deficits.

\section{Motor and TH deficits in MKO mice and correction by DHA/ALA diet}

We detected mild but significant motor deficits in Tau KO mice emerging at 9 months. DHA/ALA was fed to tau KO mice several months after the onset of TH and motor deficits, but nevertheless restored function in OKO. DHA has been demonstrated previously to be neuroprotective in PD models (Bousquet et al., 2011), suppressing JNK hyperactivation (Ma et al., 2009), which is implicated in dopaminergic neuron loss (Wang et al., 2009). The addition of ALA, which can improve mitochondrial function and limit oxidative damage (Ames, 2010; Packer and Cadenas, 2011), 
was most protective. TH loss and motor deficits reported in middle-aged tau KO mice were also prevented by early intervention with the metal chelator clioquinol (Lei et al., 2012). The well known roles of both aging and iron in promoting ROS-induced JNK activation and dopaminergic neuron loss (Lotharius et al., 2005) may explain the efficacy of diverse treatments.

The absence of behavior deficits in young and MKO is consistent with previous studies (Harada et al., 1994; Ikegami et al., 2000; Dawson et al., 2001; Roberson et al., 2007), but OKO showed deficits in retention and mild deficits in acquisition. MKO exhibited motor deficits similar to OKO, but without MWM memory probe deficits. The marked loss of synaptic proteins implicated in memory in the hippocampus and their recovery with treatment suggest that MWM deficits may result not just from motor dysfunction, but also cognitive deficits.

In contrast, another study reported no $\mathrm{TH}$, motor, or behavioral deficits in OKO (Morris et al., 2013). One study difference is that their OKO mice that did not exhibit deficits were barrier maintained, unlike our specific pathogen-free-maintained colony, which were exposed to more pathogens, potentially increasing neuroinflammation. Alternatively, our chow lacks fish meal, the source of DHA in many rodent chows, and lack of dietary DHA can reduce brain DHA (Gamoh et al., 2001) and may increase sensitivity to tau deletion. OKO mice lacking deficits were raised on PicoLab diet 20 containing $0.87 \%$ fatty acids as DHA or $1.3 \mu \mathrm{mol} / \mathrm{g}$ chow (Basselin et al., 2010), which delivers $\sim 6.5$ $\mu \mathrm{mol}$ DHA/d/mouse. Because DHA synthesis rates from 18:n-3 precursor are very low (e.g., $0.045-1.5 \mu \mathrm{mol} / \mathrm{d}$ in rats, which are five times larger than mice; Domenichiello et al., 2014), this $\sim 6.5$ $\mu \mathrm{M} / \mathrm{d}$ dose could explain the absence of deficits with this Pico Diet and our detection of deficits and correction by DHA with our 5015 diet containing only 18:n-3.

\section{Upregulation of MAPs and MAP1B activity in middle-aged KO mice}

Both MAP1A and MAP1B are important for developing axons and dendrites. Localization of MAP1A is predominantly dendritic (Schoenfeld et al., 1989), whereas that of MAP1B is predominantly axonal (Tucker and Matus, 1987; Denny, 1991). Similar to previous studies (Bloom et al., 1985; Harada et al., 1994; Ikegami et al., 2000; Takei et al., 2000), we observed an early compensatory response to tau deletion, including increased MAP1A and MAP1B, but also demonstrate that increased MAPs correspond to preservation of synaptic proteins.

MAP2 was elevated in MKO and has a primary somatodendritic distribution with functions including nucleation and stabilization of microtubules, regulation of organelle transport, and anchoring regulatory proteins including signal transduction kinases (Sánchez et al., 2000b). Functional redundancy of MAP1B with MAP2 and tau suggest common actions in growing axons and dendrites (DiTella et al., 1996; Takei et al., 2000; Teng et al., 2001; Riederer, 2007). Increased MAP2 could contribute to the protective effects of tau deletion in young transgenic mice with dominant mutations in Amyloid Precursor Protein (APP) on neuritic dystrophy, behavioral deficits, and premature mortality (Roberson et al., 2007; Ittner et al., 2010). Because intraneuronal $\beta$-amyloid is associated with a reduction in MAP2 in neurites and postsynaptic compartments (Takahashi et al., 2013), elevated MAP2 in MKO may provide a protective mechanism.

\section{MWM deficits and loss of synapse and functional MAPs in the OKO mice}

Aging resulted in significant excitatory synaptic protein loss in tau $\mathrm{KO}$ mice, resembling early $\mathrm{AD}$, in which drebrin (Harigaya et al., 1996) and NR2B, but not NR1 (Sze et al., 2001) or GABA (Rissman et al., 2003), are lost. This shows that, independently of protein aggregates, $\mathrm{LOF}$ of tau and aging can contribute to $\mathrm{AD}$ like synaptic protein loss.

Critical microtubule (MT) dynamic roles in axonal and dendritic processes are modulated by phosphorylation of MAPs in adult brain (Sánchez et al., 2000b; Riederer, 2007). In contrast to protective compensatory responses in MAPs in MKO, OKO showed loss of functional MAP2 and MAP1B. MAP1B can be phosphorylated by GSK3 $\beta$ at Ser 1260 and Thr1265 (Trivedi et al., 2005) or by JNK (Soares et al., 2007), both which are important for MAP2 regulation of MT dynamics (Chang et al., 2003) and altered in the OKO. There was also loss of $200 \mathrm{kDa}$ SMI31, which detects, not only phospho-neurofilament, but also MAP1B phosphorylated by GSK3 $\beta$ and other serine/threonine kinases in the conserved 1244-1264 region (Johnstone et al., 1997; Trivedi et al., 2005). In AD, there is reduced expression of MAP1B and MAP2 (Parachikova et al., 2007) and colocalization with tau in NFTs and dystrophic neurites, suggesting similar loss of MAP MT binding and somatodendritic redistribution (Hasegawa et al., 1990; Ulloa et al., 1994; Alonso et al., 1996; Adlard and Vickers, 2002).

MAPs support microtubule-based transport of organelles and synaptic components, including vesicles containing glutamate receptor subunits and other cargoes to postsynaptic sites (Setou et al., 2000), and MAP1B loss contributes to reduced plasticity in aging (Wagner et al., 1992; Wagner et al., 2000). Our findings argue that compensatory protective responses in MAPs may be compromised with age. Therefore, early synaptic deficits in $\mathrm{AD}$ may originate in part from the loss of normal MAPs and their functions, including HSP and Fyn transport.

Our data demonstrate a significant reduction in acetylatedtubulin in old, but not MKO mice, consistent with failed compensation of MAP-regulated microtubule stability. Abundant evidence implicates microtubule instability in $\mathrm{AD}$ (Alonso et al., 1996; Ishihara et al., 1999; Zhang et al., 2005), including reduced acetylated-tubulin (Hempen and Brion, 1996; Brion et al., 2001). Three-dimensional reconstruction shows that microtubule networks are disrupted in tangle-bearing neurons (Ellisman et al., 1988), but MT number and length in AD pyramidal neurons is reduced independently of paired helical filaments and controls also show age-dependent decreases in microtubule density (Cash et al., 2003).

OKO displayed increased pJNK and reduced functional MAP2, potentially affecting MT stability. Hyperactivation of JNK appears to play a pathogenic role in $\mathrm{AD}$ patients and $\mathrm{AD}$ models (Lagalwar et al., 2006; Leroy et al., 2007) and can disrupt kinesin-1 microtubule binding and related cargo delivery, leading to loss of synaptic function (Morfini et al., 2005).

Unlike JNK, levels of GSK3 were reduced in OKO. GSK-3 phosphorylation of MAP1B acts as a molecular switch controlling MAP1B microtubule dynamics in axons and growth cones (Trivedi et al., 2005). Constitutive GSK3 $\beta$ activity at excitatory synapses is critical for memory and LTD (Kemp and Bashir, 2001; Peineau et al., 2007; Hu et al., 2009), so loss in OKO could contribute to deficits.

Fyn was reduced in OKO. Although aberrant activation of Fyn exacerbates $\mathrm{A} \beta$ synaptotoxicity in a tau-dependent manner (Ittner et al., 2010), minimal levels of postsynaptic Fyn 
maintained by compensatory MAPs are critical for NMDA receptor regulation.

As in Tg2576 mice overexpressing human APP695 with the "Swedish" mutation (APPSw) (Calon et al., 2004), OKO displayed a similar DHA-protective effect on selective excitatory synaptic protein loss. However, DHA also restored hippocampal $\mathrm{NR} 2 \mathrm{~B}$ in OKO, but not in the APPSw mice. Combined DHA/ ALA protected drebrin, PSD-95, NR2B, Fyn, and acetylated $\alpha$-tubulin better than DHA alone, which is consistent with predicted synergistic effects between DHA and ALA from a small clinical trial (Shinto et al., 2014). ALA, an essential mitochondrial enzyme cofactor, can reverse mitochondrial defects associated with age-related memory loss (Liu et al., 2002). DHA and DHA/ ALA significantly reduced the activity of JNK and increased GSK3 $\beta$, demonstrating novel mechanisms to account for DHA's potential cognitive benefit in aging and AD.

In summary, loss of MAP function in the hippocampus of OKO was associated with poor MWM performance, synaptic deficits, and destabilization of microtubules, whereas at earlier ages, other MT-stabilizing MAPs may compensate for tau LOF. The observed changes in JNK and GSK3 $\beta$, which were corrected by DHA and DHA/ALA, could explain age-dependent modulation of MAPs regulating microtubule dynamics/stability. The combination of DHA/ALA was more effective in protecting motor deficits NR2B, Fyn, acetylated $\alpha$-tubulin, and TH than DHA alone. Restoration of kinase-regulated MAPs that compensate for tau LOF with aging and preserve synaptic plasticity should be considered as an additional avenue in the search for new approaches for the prevention of age-related cognitive deficits. Insufficient dietary DHA in Western diets is a significant problem (Flock et al., 2013).

\section{References}

Adlard PA, Vickers JC (2002) Morphologically distinct plaque types differentially affect dendritic structure and organisation in the early and late stages of Alzheimer's disease. Acta Neuropathol 103:377-383. CrossRef Medline

Alonso AC, Grundke-Iqbal I, Iqbal K (1996) Alzheimer's disease hyperphosphorylated tau sequesters normal tau into tangles of filaments and disassembles microtubules. Nat Med 2:783-787. CrossRef Medline

Ames BN (2010) Optimal micronutrients delay mitochondrial decay and age-associated diseases. Mech Ageing Dev 131:473-479. CrossRef Medline

Arriagada PV, Growdon JH, Hedley-Whyte ET, Hyman BT (1992) Neurofibrillary tangles but not senile plaques parallel duration and severity of Alzheimer's disease. Neurology 42:631-639. CrossRef Medline

Avíla J, Ulloa L, Diez-Guerra J, Díaz-Nido J (1994) Role of phosphorylated MAPlB in neuritogenesis. Cell Biol Int 18:309-314. CrossRef Medline

Basselin M, Rosa AO, Ramadan E, Cheon Y, Chang L, Chen M, Greenstein D, Wohltmann M, Turk J, Rapoport SI (2010) Imaging decreased brain docosahexaenoic acid metabolism and signaling in iPLA(2)beta (VIA)deficient mice. J Lipid Res 51:3166-3173. CrossRef Medline

Bloom GS, Luca FC, Vallee RB (1985) Microtubule-associated protein 1B: identification of a major component of the neuronal cytoskeleton. Proc Natl Acad Sci U S A 82:5404-5408. CrossRef Medline

Bousquet M, Gue K, Emond V, Julien P, Kang JX, Cicchetti F, Calon F (2011) Transgenic conversion of omega- 6 into omega- 3 fatty acids in a mouse model of Parkinson's disease. J Lipid Res 52:263-271. CrossRef Medline

Brion JP, Anderton BH, Authelet M, Dayanandan R, Leroy K, Lovestone S, Octave JN, Pradier L, Touchet N, Tremp G (2001) Neurofibrillary tangles and tau phosphorylation. Biochem Soc Symp 67:81-88. Medline

Calon F, Lim GP, Yang F, Morihara T, Teter B, Ubeda O, Rostaing P, Triller A, Salem N Jr, Ashe KH, Frautschy SA, Cole GM (2004) Docosahexaenoic acid protects from dendritic pathology in an Alzheimer's disease mouse model. Neuron 43:633-645. CrossRef Medline

Cash AD, Aliev G, Siedlak SL, Nunomura A, Fujioka H, Zhu X, Raina AK, Vinters HV, Tabaton M, Johnson AB, Paula-Barbosa M, Avíla J, Jones PK, Castellani RJ, Smith MA, Perry G (2003) Microtubule reduction in Alz- heimer's disease and aging is independent of tau filament formation. Am J Pathol 162:1623-1627. CrossRef Medline

Chang L, Jones Y, Ellisman MH, Goldstein LS, Karin M (2003) JNK1 is required for maintenance of neuronal microtubules and controls phosphorylation of microtubule-associated proteins. Dev Cell 4:521-533. CrossRef Medline

Chiu CC, Su KP, Cheng TC, Liu HC, Chang CJ, Dewey ME, Stewart R, Huang SY (2008) The effects of omega-3 fatty acids monotherapy in Alzheimer's disease and mild cognitive impairment: a preliminary randomized double-blind placebo-controlled study. Prog Neuropsychopharmacol Biol Psychiatry 32:1538-1544. CrossRef Medline

Cole GM, Ma QL, Frautschy SA (2010) Dietary fatty acids and the aging brain. Nutr Rev 68:S102-S111. CrossRef Medline

Dawson HN, Ferreira A, Eyster MV, Ghoshal N, Binder LI, Vitek MP (2001) Inhibition of neuronal maturation in primary hippocampal neurons from tau deficient mice. J Cell Sci 114:1179-1187. Medline

Dawson HN, Cantillana V, Jansen M, Wang H, Vitek MP, Wilcock DM, Lynch JR, Laskowitz DT (2010) Loss of tau elicits axonal degeneration in a mouse model of Alzheimer's disease. Neuroscience 169:516-531. CrossRef Medline

Dehmelt L, Halpain S (2005) The MAP2/Tau family of microtubuleassociated proteins. Genome Biol 6:204. CrossRef Medline

Denk F, Wade-Martins R (2009) Knock-out and transgenic mouse models of tauopathies. Neurobiol Aging 30:1-13. CrossRef Medline

Denny JB (1991) MAP5 in cultured hippocampal neurons: expression diminishes with time and growth cones are not immunostained. J Neurocytol 20:627-636. CrossRef Medline

DiTella MC, Feiguin F, Carri N, Kosik KS, Cáceres A (1996) MAP-1B/TAU functional redundancy during laminin-enhanced axonal growth. J Cell Sci 109:467-477. Medline

Domenichiello AF, Chen CT, Trepanier MO, Stavro PM, Bazinet RP (2014) Whole body synthesis rates of DHA from $\alpha$-linolenic acid are greater than brain DHA accretion and uptake rates in adult rats. J Lipid Res 55:62-74. CrossRef Medline

Ellisman M, Ranganathan R, Deerinck T, Young S, Terry R, Mirra S (1988) Neuronal fibrillar cytoskeleton and endomembrane system organization in Alzheimer's disease. In: Alterations in the neuronal cytoskeleton in Alzheimer disease: advances in behavioral biology (Perry G, ed), pp 6173. New York: Springer.

Flock MR, Harris WS, Kris-Etherton PM (2013) Long-chain omega-3 fatty acids: time to establish a dietary reference intake. Nutr Rev 71:692-707. CrossRef Medline

Gamblin TC, Chen F, Zambrano A, Abraha A, Lagalwar S, Guillozet AL, Lu M, Fu Y, Garcia-Sierra F, LaPointe N, Miller R, Berry RW, Binder LI, Cryns VL (2003) Caspase cleavage of tau: linking amyloid and neurofibrillary tangles in Alzheimer's disease. Proc Natl Acad Sci U S A 100: 10032-10037. CrossRef Medline

Gamoh S, Hashimoto M, Hossain S, Masumura S (2001) Chronic administration of docosahexaenoic acid improves the performance of radial arm maze task in aged rats. Clin Exp Pharmacol Physiol 28:266-270. CrossRef Medline

Goold RG, Owen R, Gordon-Weeks PR (1999) Glycogen synthase kinase 3beta phosphorylation of microtubule-associated protein $1 \mathrm{~B}$ regulates the stability of microtubules in growth cones. J Cell Sci 112:3373-3384. Medline

Guillozet AL, Weintraub S, Mash DC, Mesulam MM (2003) Neurofibrillary tangles, amyloid, and memory in aging and mild cognitive impairment. Arch Neurol 60:729-736. CrossRef Medline

Guyenet SJ, Furrer SA, Damian VM, Baughan TD, La Spada AR, Garden GA (2010) A simple composite phenotype scoring system for evaluating mouse models of cerebellar ataxia. J Vis Exp 39:pii:1787. CrossRef Medline

Harada A, Oguchi K, Okabe S, Kuno J, Terada S, Ohshima T, Sato-Yoshitake R, Takei Y, Noda T, Hirokawa N (1994) Altered microtubule organization in small-calibre axons of mice lacking tau protein. Nature 369:488 491. CrossRef Medline

Harigaya Y, Shoji M, Shirao T, Hirai S (1996) Disappearance of actinbinding protein, drebrin, from hippocampal synapses in Alzheimer's disease. J Neurosci Res 43:87-92. CrossRef Medline

Hasegawa M, Arai T, Ihara Y (1990) Immunochemical evidence that fragments of phosphorylated MAP5 (MAP1B) are bound to neurofibrillary tangles in Alzheimer's disease. Neuron 4:909-918. CrossRef Medline 
Hempen B, Brion JP (1996) Reduction of acetylated $\alpha$-tubulin immunoreactivity in neurofibrillary tangle-bearing neurons in Alzheimer's disease. J Neuropathol Exp Neurol 55:964-972. CrossRef Medline

Hu S, Begum AN, Jones MR, Oh MS, Beech WK, Beech BH, Yang F, Chen P, Ubeda OJ, Kim PC, Davies P, Ma Q, Cole GM, Frautschy SA (2009) GSK3 inhibitors show benefits in an Alzheimer's disease (AD) model of neurodegeneration but adverse effects in control animals. Neurobiol Dis 33:193-206. CrossRef Medline

Ikegami S, Harada A, Hirokawa N (2000) Muscle weakness, hyperactivity, and impairment in fear conditioning in tau-deficient mice. Neurosci Lett 279:129-132. CrossRef Medline

Ishihara T, Hong M, Zhang B, Nakagawa Y, Lee MK, Trojanowski JQ, Lee VM (1999) Age-dependent emergence and progression of a tauopathy in transgenic mice overexpressing the shortest human tau isoform. Neuron 24:751-762. CrossRef Medline

Ittner LM, Ke YD, Delerue F, Bi M, Gladbach A, van Eersel J, Wolfing H, Chieng BC, Christie MJ, Napier IA, Eckert A, Staufenbiel M, Hardeman E, Götz J (2010) Dendritic function of tau mediates amyloid-beta toxicity in Alzheimer's disease mouse models. Cell 142:387-397. CrossRef Medline

Jicha GA, Lane E, Vincent I, Otvos L Jr, Hoffmann R, Davies P (1997) A conformation- and phosphorylation-dependent antibody recognizing the paired helical filaments of Alzheimer's disease. J Neurochem 69:20872095. CrossRef Medline

Johnstone M, Goold RG, Bei D, Fischer I, Gordon-Weeks PR (1997a) Localisation of microtubule-associated protein $1 \mathrm{~B}$ phosphorylation sites recognised by monoclonal antibody SMI-31. J Neurochem 69:1417-1424. CrossRef Medline

Ke YD, Suchowerska AK, van der Hoven J, De Silva DM, Wu CW, van Eersel J, Ittner A, Ittner LM (2012) Lessons from tau-deficient mice. Int J Alzheimers Dis 2012:873270. CrossRef Medline

Kemp N, Bashir ZI (2001) Long-term depression: a cascade of induction and expression mechanisms. Prog Neurobiol 65:339-365. CrossRef Medline

Lagalwar S, Guillozet-Bongaarts AL, Berry RW, Binder LI (2006) Formation of phospho-SAPK/JNK granules in the hippocampus is an early event in Alzheimer disease. J Neuropathol Exp Neurol 65:455-464. CrossRef Medline

Lei P, Ayton S, Finkelstein DI, Spoerri L, Ciccotosto GD, Wright DK, Wong BX, Adlard PA, Cherny RA, Lam LQ, Roberts BR, Volitakis I, Egan GF, McLean CA, Cappai R, Duce JA, Bush AI (2012) Tau deficiency induces parkinsonism with dementia by impairing APP-mediated iron export. Nat Med 18:291-295. CrossRef Medline

Leroy K, Bretteville A, Schindowski K, Gilissen E, Authelet M, De Decker R, Yilmaz Z, Buée L, Brion JP (2007) Early axonopathy preceding neurofibrillary tangles in mutant tau transgenic mice. Am J Pathol 171:976-992. CrossRef Medline

Lim GP, Calon F, Morihara T, Yang F, Teter B, Ubeda O, Salem N Jr, Frautschy SA, Cole GM (2005) A diet enriched with the omega-3 fatty acid docosahexaenoic acid reduces amyloid burden in an aged Alzheimer mouse model. J Neurosci 25:3032-3040. CrossRef Medline

Liu J, Head E, Gharib AM, Yuan W, Ingersoll RT, Hagen TM, Cotman CW, Ames BN (2002) Memory loss in old rats is associated with brain mitochondrial decay and RNA/DNA oxidation: partial reversal by feeding acetyl-L-carnitine and/or R-alpha-lipoic acid. Proc Natl Acad Sci U S A 99:2356-2361. CrossRef Medline

Lotharius J, Falsig J, van Beek J, Payne S, Dringen R, Brundin P, Leist M (2005) Progressive degeneration of human mesencephalic neuronderived cells triggered by dopamine-dependent oxidative stress is dependent on the mixed-lineage kinase pathway. J Neurosci 25:6329-6342. CrossRef Medline

Ma QL, Lim GP, Harris-White ME, Yang F, Ambegaokar SS, Ubeda OJ, Glabe CG, Teter B, Frautschy SA, Cole GM (2006) Antibodies against beta-amyloid reduce Abeta oligomers, glycogen synthase kinase-3beta activation and tau phosphorylation in vivo and in vitro. J Neurosci Res 83:374-384. CrossRef Medline

Ma QL, Yang F, Rosario ER, Ubeda OJ, Beech W, Gant DJ, Chen PP, Hudspeth B, Chen C, Zhao Y, Vinters HV, Frautschy SA, Cole GM (2009) Beta-amyloid oligomers induce phosphorylation of tau and inactivation of insulin receptor substrate via c-Jun N-terminal kinase signaling: suppression by omega-3 fatty acids and curcumin. J Neurosci 29:9078-9089. CrossRef Medline
Morfini G, Pigino G, Brady ST (2005) Polyglutamine expansion diseases: failing to deliver. Trends Mol Med 11:64-70. CrossRef Medline

Morris M, Hamto P, Adame A, Devidze N, Masliah E, Mucke L (2013) Ageappropriate cognition and subtle dopamine-independent motor deficits in aged tau knockout mice. Neurobiol Aging 34:1523-1529. CrossRef Medline

Morris R (1984) Developments of a water-maze procedure for studying spatial learning in the rat. J Neurosci Methods 11:47-60. CrossRef Medline

Nieto A, Montejo de Garcini E, Avíla J (1989) Altered levels of microtubule proteins in brains of Alzheimer's disease patients. Acta Neuropathol 78: 47-51. CrossRef Medline

Packer L, Cadenas E (2011) Lipoic acid: energy metabolism and redox regulation of transcription and cell signaling. J Clin Biochem Nutr 48:26-32. CrossRef Medline

Parachikova A, Agadjanyan MG, Cribbs DH, Blurton-Jones M, Perreau V, Rogers J, Beach TG, Cotman CW (2007) Inflammatory changes parallel the early stages of Alzheimer disease. Neurobiol Aging 28:1821-1833. CrossRef Medline

Peineau S, Taghibiglou C, Bradley C, Wong TP, Liu L, Lu J, Lo E, Wu D, Saule E, Bouschet T, Matthews P, Isaac JT, Bortolotto ZA, Wang YT, Collingridge GL (2007) LTP inhibits LTD in the hippocampus via regulation of GSK3beta. Neuron 53:703-717. CrossRef Medline

Quinn JF, Bussiere JR, Hammond RS, Montine TJ, Henson E, Jones RE, Stackman RW Jr (2007) Chronic dietary $\alpha$-lipoic acid reduces deficits in hippocampal memory of aged Tg2576 mice. Neurobiol Aging 28:213225. CrossRef Medline

Quinn JF, Raman R, Thomas RG, Yurko-Mauro K, Nelson EB, Van Dyck C, Galvin JE, Emond J, Jack CR Jr, Weiner M, Shinto L, Aisen PS (2010) Docosahexaenoic acid supplementation and cognitive decline in Alzheimer disease: a randomized trial. JAMA 304:1903-1911. CrossRef Medline

Reynolds CH, Betts JC, Blackstock WP, Nebreda AR, Anderton BH (2000) Phosphorylation sites on tau identified by nanoelectrospray mass spectrometry: differences in vitro between the mitogen-activated protein kinases ERK2, c-Jun N-terminal kinase and P38, and glycogen synthase kinase-3beta. J Neurochem 74:1587-1595. CrossRef Medline

Riederer BM (2007) Microtubule-associated protein 1B, a growthassociated and phosphorylated scaffold protein. Brain Res Bull 71:541558. CrossRef Medline

Rissman RA, Mishizen-Eberz AJ, Carter TL, Wolfe BB, De Blas AL, Miralles CP, Ikonomovic MD, Armstrong DM (2003) Biochemical analysis of GABA(A) receptor subunits alpha 1 , alpha 5 , beta 1 , beta 2 in the hippocampus of patients with Alzheimer's disease neuropathology. Neuroscience 120:695-704. CrossRef Medline

Roberson ED, Scearce-Levie K, Palop JJ, Yan F, Cheng IH, Wu T, Gerstein H, Yu GQ, Mucke L (2007) Reducing endogenous tau ameliorates amyloid beta-induced deficits in an Alzheimer's disease mouse model. Science 316:750-754. CrossRef Medline

Sánchez C, Díaz-Nido J, Avíla J (1995) Variations in in vivo phosphorylation at the proline-rich domain of the microtubule-associated protein 2 (MAP2) during rat brain development. Biochem J 306:481-487. Medline

Sánchez C, Pérez M, Avíla J (2000a) GSK3beta-mediated phosphorylation of the microtubule-associated protein $2 \mathrm{C}$ (MAP2C) prevents microtubule bundling. Eur J Cell Biol 79:252-260. CrossRef Medline

Sánchez C, Díaz-Nido J, Avíla J (2000b) Phosphorylation of microtubuleassociated protein 2 (MAP2) and its relevance for the regulation of the neuronal cytoskeleton function. Prog Neurobiol 61:133-168. CrossRef Medline

Santacruz K, Lewis J, Spires T, Paulson J, Kotilinek L, Ingelsson M, Guimaraes A, DeTure M, Ramsden M, McGowan E, Forster C, Yue M, Orne J, Janus C, Mariash A, Kuskowski M, Hyman B, Hutton M, Ashe KH (2005) Tau suppression in a neurodegenerative mouse model improves memory function. Science 309:476-481. CrossRef Medline

Schoenfeld TA, McKerracher L, Obar R, Vallee RB (1989) MAP 1A and MAP 1B are structurally related microtubule associated proteins with distinct developmental patterns in the CNS. J Neurosci 9:1712-1730. Medline

Setou M, Nakagawa T, Seog DH, Hirokawa N (2000) Kinesin superfamily motor protein KIF17 and mLin-10 in NMDA receptor-containing vesicle transport. Science 288:1796-1802. CrossRef Medline

Shinto L, Quinn J, Montine T, Dodge HH, Woodward W, Baldauf-Wagner S, Waichunas D, Bumgarner L, Bourdette D, Silbert L, Kaye J (2014) A randomized placebo-controlled pilot trial of omega-3 fatty acids and al- 
pha lipoic acid in Alzheimer's disease. J Alzheimers Dis 38:111-120. CrossRef Medline

Soares S, Barnat M, Salim C, von Boxberg Y, Ravaille-Veron M, Nothias F (2007) Extensive structural remodeling of the injured spinal cord revealed by phosphorylated MAP1B in sprouting axons and degenerating neurons. Eur J Neurosci 26:1446-1461. CrossRef Medline

Sze C, Bi H, Kleinschmidt-DeMasters BK, Filley CM, Martin LJ (2001) N-Methyl-D-aspartate receptor subunit proteins and their phosphorylation status are altered selectively in Alzheimer's disease. J Neurol Sci 182: 151-159. CrossRef Medline

Takahashi RH, Capetillo-Zarate E, Lin MT, Milner TA, Gouras GK (2013) Accumulation of intraneuronal beta-amyloid 42 peptides is associated with early changes in microtubule-associated protein 2 in neurites and synapses. PLoS One 8:e51965. CrossRef Medline

Takei Y, Teng J, Harada A, Hirokawa N (2000) Defects in axonal elongation and neuronal migration in mice with disrupted tau and maplb genes. J Cell Biol 150:989-1000. CrossRef Medline

Teng J, Takei Y, Harada A, Nakata T, Chen J, Hirokawa N (2001) Synergistic effects of MAP2 and MAP1B knockout in neuronal migration, dendritic outgrowth, and microtubule organization. J Cell Biol 155:65-76. CrossRef Medline

Trivedi N, Marsh P, Goold RG, Wood-Kaczmar A, Gordon-Weeks PR (2005a) Glycogen synthase kinase-3beta phosphorylation of MAP1B at Ser1260 and Thr1265 is spatially restricted to growing axons. J Cell Sci 118:993-1005. CrossRef Medline
Tucker RP, Matus AI (1987) Developmental regulation of two microtubuleassociated proteins (MAP2 and MAP5) in the embryonic avian retina. Development 101:535-546. Medline

Ulloa L, Montejo de Garcini E, Gómez-Ramos P, Morán MA, Avíla J (1994) Microtubule-associated protein MAP1B showing a fetal phosphorylation pattern is present in sites of neurofibrillary degeneration in brains of Alzheimer's disease patients. Brain Res Mol Brain Res 26:113-122. CrossRef Medline

Wagner AP, Reck G, Platt D (1992) Dynamics of gene expression for microtubule-associated protein MAP1B, embryonic alpha-tubulin and late neural beta-tubulin mRNAs in the hippocampus of aged rats. Biochem Biophys Res Commun 184:292-299. CrossRef Medline

Wagner AP, Schmoll H, Badan I, Platt D, Kessler C (2000) Brain plasticity: to what extent do aged animals retain the capacity to coordinate gene activity in response to acute challenges. Exp Gerontol 35:1211-1227. CrossRef Medline

Wang Y, Zhang Y, Wei Z, Li H, Zhou H, Zhang Z, Zhang Z (2009) JNK inhibitor protects dopaminergic neurons by reducing COX-2 expression in the MPTP mouse model of subacute Parkinson's disease. J Neurol Sci 285:172-177. CrossRef Medline

Zhang B, Maiti A, Shively S, Lakhani F, McDonald-Jones G, Bruce J, Lee EB, Xie SX, Joyce S, Li C, Toleikis PM, Lee VM, Trojanowski JQ (2005) Microtubule-binding drugs offset tau sequestration by stabilizing microtubules and reversing fast axonal transport deficits in a tauopathy model. Proc Natl Acad Sci U S A 102:227-231. CrossRef Medline 